\title{
Design of new gluten-free extruded rice snack products supplemented with fresh vegetable pulps: the effect on processing and functional properties
}

\author{
Katarzyna Lisiecka ${ }^{1}$, Agnieszka Wójtowicz ${ }^{1}$ (1) , Abdallah Bouasla ${ }^{2}$, and Kamila Kasprzak ${ }^{3}$ (] \\ ${ }^{1}$ Department of Thermal Technology and Food Process Engineering, University of Life Sciences in Lublin, \\ Głęboka 31, 20-612, Lublin, Poland \\ ${ }^{2}$ Laboratoire de Génie Agro-Alimentaire, Institut de la Nutrition, de l'Alimentation et des Technologies Agro-Alimentaires, \\ Université Frères Mentouri Constantine 1, Algeria \\ ${ }^{3}$ Department of Inorganic Chemistry, Medical University of Lublin, Chodźki 4a, 20-093 Lublin, Poland
}

Received August 6, 2020; accepted January 3, 2021

\begin{abstract}
The aim of this study was to obtain ready-to-eat gluten-free snack products based on rice with the addition of fresh beetroot, carrot, kale, leek and onion pulps in the amounts of 2.5, $5.0,7.5$, and $10.0 \%(\mathrm{w} / \mathrm{w})$. The snacks were processed using extrusion-cooking at various screw speeds (80, 100 and $120 \mathrm{rpm})$. The total phenolics content, processing efficiency, specific mechanical energy, expansion ratio, bulk density, colour and texture profile were determined. The results showed that the type and amount of vegetable pulp added had a significant effect on the total phenolics content, expansion ratio, bulk density and colour profile of the newly produced gluten-free snacks. Generally, the screw speed had a significant effect on processing efficiency. Moreover, the interactions between the content of the vegetable additives and the screw speed had significant effects on the total phenolics content, processing efficiency, physical properties and texture of the snack products. The research demonstrated the possibility of using fresh vegetable pulps as nutritionally valuable ingredients for glutenfree extruded snacks.
\end{abstract}

Keyw ords: extrusion-cooking, extruded snack, vegetable pulp, processing conditions, extrusion-cooking screw speed, texture

\section{INTRODUCTION}

Vegetables are valuable components of the average daily diet due to their positive role in preventing or protecting against many diseases, including cardiovascular

\footnotetext{
*Corresponding author e-mail: agnieszka.wojtowicz@up.lublin.pl
}

diseases, cancer and others (Baars et al., 2019). These beneficial effects may be explained by the presence of several bioactive components (polyphenols, vitamins, minerals) that act to improve the overall health of the individual. A healthy diet for adults should include vegetable consumption within the range of 400 to $500 \mathrm{~g}$ per day. This dose is sufficient to improve the odds of avoiding chronic diseases (Oyebode et al., 2014). Gluten intolerance and celiac disease are examples of genetically determined chronic diseases. People with celiac disease are permanently sensitive to gluten due to minor intestinal mucosal injury and malabsorption (Usai-Satta et al., 2017). A strict gluten-free diet must be followed throughout the lifespan of the individual concerned and inevitably restricts social activity and impinges on the quality of life of the patient (Bascuñan et al., 2017). Rice flour is an acceptable alternative to wheat flours for those with gluten intolerance.

Snack products produced by the extrusion-cooking process are very popular and have a favourable economic position among snack food items - which can be prepared in a variety of ways (e.g. fried or baked). In general terms, most extruded snack products are produced with cereal

(C) 2021 Institute of Agrophysics, Polish Academy of Sciences 
flours or starches (Korkerd et al., 2016). Their great advantages are specific marketable features, including crispness and visual appeal. The production process, besides the heating, shearing and pressure treatment allows for the simultaneous mixing of various raw materials, which in turn makes it possible to obtain enriched final products. The optimal raw materials for the production of directly expanded snack products are corn and rice flours or grits (Pęksa et al., 2017). However, snack foods based on corn and rice are nutrient-poor. Therefore, it is recommended to enrich the composition of corn or rice snacks with various valuable additives in order to enhance their health benefits (Altan et al., 2008).

In the literature, some information may be found concerning supplemented gluten-free snacks based on corn with various additives, such as Moldavian dragonhead leaves, tomato powder, powdered fruit (Wójtowicz et al., 2017, 2018,2019 ) or with chickpea, defatted soy flour, guar gum (Shah et al., 2017), and many others. For the human diet, in the search for new natural sources of antioxidants, it is recommended to apply the determination of the total phenolics content (TPC) as an indicator of the antioxidant potential of possible foodstuffs (Lucas González et al., 2016). Of particular note is the fact that, in many cases, phenolic compounds are activated after the damage of plant tissues. In previous studies, for example, an increase in the TPC was observed due to the contribution of powdered tomato, broccoli flour and cauliflower by-products (Bisharat et al., 2015; Wójtowicz et al., 2018; Stojceska et al., 2009). To date, corn extrudates have been fortified using dehydrated broccoli, olive paste (Bisharat et al., 2015), powdered tomato (Wójtowicz et al., 2018), red cabbage (Stojceska et al., 2009), dried fruit (Wójtowicz et al., 2019), pumpkin flour (Poliszko et al., 2019) or cauliflower and fruit pomace by-products (Stojceska et al., 2008; Paraman et al., 2015).

There is a growing market for extruded sweet or savoury snacks. At the same time, there is a particular focus on the possibility of saving water and energy in the food production sector (Food Industry Sustainability Strategy, 2006). The addition of pulp from fresh vegetables serves not only to enhance the development of new types of products, it also allows for a significant reduction in the consumption of water and energy during a processing which results in the omission of the drying step (Lisiecka and Wójtowicz, 2020). However, to the best of our knowledge, no studies have been carried out to date in order to produce ready-toeat gluten-free extrudates supplemented with fresh vegetable pulp. The presentation of the following research will provide an answer as to whether it is possible to enrich rice snacks with fresh vegetable pulps in order to achieve desirable and valuable snack products to be enjoyed by those with gluten intolerance or celiac disease. Hence, this study is aimed at evaluating the effect of the addition of selected vegetable pulps and screw speeds on certain properties of gluten-free rice snacks.

\section{MATERIALS AND METHODS}

The basic raw material used to prepare gluten-free snacks was rice flour (Aro, MAKRO Cash and Carry, Lublin, Poland) with a particle size of below $500 \mu \mathrm{m}$, a caloric value of $1441 \mathrm{~kJ} / 339 \mathrm{kcal}, 1.0 \%$ fat, $74.0 \%$ carbohydrates, $1.6 \%$ total fibre, $8.2 \%$ protein (producer's data) and a moisture content of $13.1 \%$. Selected vegetables were used as additives, including beetroot (B), carrot $(\mathrm{C})$, kale (K), leek (L) and onion $(\mathrm{O})$ (purchased from the local market). The fresh vegetables were cleaned, peeled, drained and pulped using a laboratory grinder (Grindomix GM 200, RETSCH GmbH, Haan, Germany) with $0.5 \mathrm{~mm}$ sieve openings to achieve a pulp with a particle size below $500 \mu \mathrm{m}$. The moisture content of the fresh pulp was as follows: beetroot $92.09 \%$, carrot $87.10 \%$, kale $85.89 \%$, leek $87.40 \%$ and onion $87.35 \%$.

The freshly pulped vegetables were blended with rice flour in the following amounts; 2.5, 5.0, 7.5 and 10.0\% $(\mathrm{w} / \mathrm{w})$, while $100 \%$ rice flour snack products were used as a control. In the preliminary study, it was found that a $10.0 \%(\mathrm{w} / \mathrm{w})$ level is the maximum that can be applied to rice-based snacks that are processed with a single screw extruder to achieve expanded products. The blends were set aside for $2 \mathrm{~h}$ to equilibrate the moisture content supplied by the fresh vegetables. The final moisture content of the blends was determined according to the AACC 44-19.01 method (AACC, 2011). The extruded rice and vegetable snacks were made using a single screw extruder-cooker TS-45 (Z.M.Ch. Metalchem, Gliwice, Poland) with a ratio of screw length to diameter of $\mathrm{L} / \mathrm{D}=12$ and a 3:1 compression ratio. The temperature profile in the extruder was set to $125-145-125^{\circ} \mathrm{C}$ and the screw speed was set at 80,100 and $120 \mathrm{rpm}$. The extrudates were shaped with a single open 3-mm circular forming die and cut into 30 -mm long snacks. Finally, the snack products were collected, cooled down to ambient temperature and stored in polyethylene bags at room temperature prior to testing.

Methanol extracts of the produced extrudates were prepared in order to evaluate the total phenolics content. In brief, $0.5 \mathrm{~g}$ of sample was extracted separately with $5 \mathrm{~mL}$ of $50 \%$ methanol (POCH, Gliwice, Poland). Next, the obtained extracts were shaken for $30 \mathrm{~min}$ using a rotator Multi RS-60 (Biosan, Riga, Latvia) operating at $5000 \mathrm{rpm}$. The homogenate was then centrifuged at the same velocity for 10 min using a T24D-type centrifuge (Medizinetechnik, Leipzig, Germany) (Lisiecka et al., 2019). The extraction was carried out twice. The collected supernatants were mixed and used for further analysis.

The total phenolics content was measured for the methanolic extracts. In brief, $0.05 \mathrm{~mL}$ of extract was added to $0.1 \mathrm{~mL}$ of water and $0.4 \mathrm{~mL}$ of Folin-Ciocalteau reagent (in a ratio of 1:5 with distilled water). After $3 \mathrm{~min}, 2 \mathrm{~mL}$ of $10 \%$ sodium carbonate was added and the product was vigorously shaken for $1 \mathrm{~min}$ (as a reference sample, $0.05 \mathrm{~mL}$ 
of the tested extract was replaced by 50\% methanol) (Lisiecka et al., 2019). Subsequently, the absorbance was measured at $725 \mathrm{~nm}$, using a spectrophotometer (Model 9423, ALT, USA) and the total phenolics content (TPC) was expressed in terms of a gallic acid equivalent (GAE) in $\mathrm{mg} 100 \mathrm{~g}^{-1}$ of dry weight (d.w.). The measurements were conducted twice.

For all of the tested snack products, the processing efficiency (Q) was determined in terms of the ratio of the mass of the obtained snack item at a certain time, while the specific mechanical energy (SME) was calculated based on a formula proposed by Lisiecka and Wójtowicz (2020).

The moisture content (MC) of the snack products was tested by means of applying the AACC 44-19.01 method (AACC, 2011), while the water activity (WA) was evaluated using LabMaster-aw (Novasina AG, Lachen, Switzerland) in 3 replicates.

The expansion ratio (ER) was assessed as the ratio of snack diameter to the diameter of the forming die, with the dimensions being obtained by utilizing an electronic calliper. Bulk density (BD) was evaluated as the mass divided by the equivalent volume of snack product. The tests were performed in 10 and 5 replicates for ER and BD, respectively (Wójtowicz et al., 2018).

The colour profile of the ground extrudates were defined by using a colorimeter in the CIE-Lab system in terms of lightness $\left(\mathrm{L}^{*}\right)$, as well as colour descriptors: $\mathrm{a}^{*}$ as the balance between redness $(+)$ and greenness $(-), b^{*}$ as the balance between yellowness $(+)$ and blueness $(-)$, and $\Delta \mathrm{E}$ as the total colour change within 10 repetitions (Darvishi et al., 2014; Wójtowicz et al., 2017).

The texture apparatus Zwick/Roell BDO-FB0.5TH (Zwick GmbH and Co., Ulm, Germany) equipped with a 5-blade Kramer cell was used to perform the texture profile. A single layer of snacks was placed flat in the measuring chamber and a double compression test was applied with the working head test speed of $100 \mathrm{~mm} \mathrm{~min}^{-1}$. The following textural properties were determined: hardness $(\mathrm{H})$, crispness (CR) fracturability (FR), springiness (S), and cohesiveness (C) (Wójtowicz et al., 2019). Measurements were performed in 2 replicates.

The final acceptability (A) rating for consumers' preferences was evaluated by using a 9-point hedonic scale by a panel of 15 members, where the minimum rating meant "extreme dislike" and the maximum rating meant "extreme like" (Wójtowicz et al., 2018).

A statistical analysis was performed using the Statistica 13.3 software (StatSoft, Tulsa, USA). The statistical differences between the mean values were determined by applying ANOVA, followed by the Tukey posthoc test at $\alpha=0.05$. The variables analysed were the additive amount and the screw speed applied during processing. A response surface methodology was used to show the effect of multiple variables with a second order polynomial model. An analysis of variance was conducted, and the $\mathrm{F}$ and $p$ values were determined to evaluate the effects of single variables and their interactions on snack properties.

\section{RESULTS AND DISCUSSION}

As shown in Table 1, the results of TPC indicated that along with the increased addition of fresh vegetable pulps in snack products, the total phenolics content increased as compared to the control rice snacks. This was due to the application of vegetable additives with a high antioxidant potential (Bisharat et al., 2015; Shetty et al., 2013). Moreover, Stojceska et al. (2009), in samples containing red cabbage, reported that extrusion-cooking increased the level of total antioxidant capacity and total phenolic compounds. The maximum TPC $24.83 \mathrm{mg}$ GAE $100 \mathrm{~g}^{-1}$ was noted for snack products supplemented with $10.0 \% \mathrm{w} / \mathrm{w}$ fresh beetroots and produced at $120 \mathrm{rpm}$, while the minimum level of total phenolics (7.87 mg GAE $\left.100 \mathrm{~g}^{-1}\right)$ was observed for control rice snack products extruded at $100 \mathrm{rpm}$. Samples with the highest amount of TPC characterized the highest initial moisture content of the blend, which could protect phenolic compounds from extensive destruction during extrusion-cooking. In contrast, the control snack products had the lowest TPC, as well as the lowest initial moisture content among all of the blends. This had an influence on the high shear stress noted during processing. Previous research has shown that adding external water, which increases the moisture content of extruded blends, leads to a decrease in the total phenolics content in the obtained snack items (Bisharat et al., 2015). In our research, the opposite tendency was observed because vegetables were incorporated as a fresh pulp and all of the bioactive components were retained in the processed materials, together with the water they contained. Due to the type of vegetables being used as additives, significant differences in TPC were found, especially in the cases where beetroot and carrot was used (Table 1). At the same time, small differences were observed between extrudates enriched with kale and leek, while the snacks with onion addition did not differ significantly except in the case of $10 \% \mathrm{w} / \mathrm{w}$ supplementation. Moreover, the content of vegetable additives showed significant effects on TPC for all of the tested snack products, as well as in the interactions between the additive level and the screw speed applied during processing (Table 2). However, the screw speed as a single variable had an insignificant effect on the TPC of the resulting rice snack product. Our results are similar to that reported by Bisharat et al. (2015), who found that, during the extrusion-cooking of corn snack products with broccoli flour, the phenolics content in the extrudates was not significantly affected by the screw rotational speed.

Processing efficiency and energy requirements are very important factors for the food industry. According to the results presented in Fig. 1, the highest value of $\mathrm{Q}$ was 
Table 1. Results of total phenolics content $(n=2)$, colour coordinates $L^{*}, a^{*}, b^{*}$ and total colour change $\Delta E$ index $(n=10)$ of rice snacks enriched with vegetable pulp processed at various screw speeds

\begin{tabular}{|c|c|c|c|c|c|c|c|}
\hline \multirow{2}{*}{$\begin{array}{l}\text { Vegetable } \\
\text { type }\end{array}$} & \multirow{2}{*}{$\begin{array}{c}\text { Additive } \\
\text { amount }(\%)\end{array}$} & \multirow{2}{*}{$\begin{array}{l}\text { Screw } \\
\text { speed } \\
(\mathrm{rpm})\end{array}$} & \multirow{2}{*}{$\begin{array}{c}\text { TPC } \\
\left(\mathrm{mg} \mathrm{GAE} 100 \mathrm{~g}^{-1}\right)\end{array}$} & \multicolumn{4}{|c|}{ Colour profile } \\
\hline & & & & $\mathrm{L}^{*}$ & $a^{*}$ & $b^{*}$ & $\Delta \mathrm{E}$ \\
\hline \multirow{3}{*}{$\begin{array}{l}\text { Control } \\
\text { snacks }\end{array}$} & \multirow{3}{*}{0} & 80 & $8.30 \pm 0.05^{\mathrm{a}}$ & $89.42 \pm 0.49^{\mathrm{e}}$ & $2.24 \pm 0.50^{\mathrm{ab}}$ & $15.18 \pm 0.63^{\mathrm{ab}}$ & ref \\
\hline & & 100 & $7.87 \pm 0.05^{\mathrm{a}}$ & $90.87 \pm 0.81^{\mathrm{e}}$ & $2.20 \pm 1.14^{\mathrm{ab}}$ & $15.49 \pm 1.05^{\mathrm{ab}}$ & ref \\
\hline & & 120 & $8.68 \pm 0.11^{\mathrm{a}}$ & $89.50 \pm 1.90^{\mathrm{e}}$ & $2.89 \pm 1.55^{\mathrm{ab}}$ & $15.59 \pm 2.20^{\mathrm{ab}}$ & ref \\
\hline \multirow{13}{*}{ Beetroot } & \multirow{3}{*}{2.5} & 80 & $11.71 \pm 0.54^{b}$ & $84.86 \pm 1.70^{\mathrm{cd}}$ & $2.82 \pm 0.30^{\mathrm{ab}}$ & $20.59 \pm 0.34^{\mathrm{bc}}$ & 7.10 \\
\hline & & 100 & $11.76 \pm 0.05^{\mathrm{b}}$ & $84.77 \pm 1.40^{\mathrm{cd}}$ & $2.39 \pm 0.34^{\mathrm{ab}}$ & $20.04 \pm 1.16^{\mathrm{bc}}$ & 6.57 \\
\hline & & 120 & $13.16 \pm 0.38^{\mathrm{bc}}$ & $83.67 \pm 1.49^{\mathrm{cd}}$ & $2.98 \pm 0.63^{\mathrm{ab}}$ & $19.14 \pm 1.05^{b c}$ & 6.88 \\
\hline & \multirow{3}{*}{5.0} & 80 & $14.08 \pm 0.54^{\mathrm{bc}}$ & $82.19 \pm 1.63^{\mathrm{c}}$ & $3.99 \pm 0.44^{\mathrm{b}}$ & $28.98 \pm 1.22^{\mathrm{de}}$ & 15.75 \\
\hline & & 100 & $13.00 \pm 0.43^{\mathrm{bc}}$ & $82.35 \pm 0.94^{\mathrm{c}}$ & $4.04 \pm 1.07^{\mathrm{bc}}$ & $27.75 \pm 1.32^{\mathrm{de}}$ & 14.94 \\
\hline & & 120 & $13.65 \pm 0.32^{\mathrm{bc}}$ & $82.69 \pm 0.26^{\mathrm{c}}$ & $3.98 \pm 0.27^{\mathrm{b}}$ & $27.99 \pm 1.39^{\mathrm{de}}$ & 14.22 \\
\hline & \multirow{3}{*}{7.5} & 80 & $13.27 \pm 0.20^{\mathrm{bc}}$ & $81.12 \pm 2.23^{\mathrm{c}}$ & $5.47 \pm 1.45^{\mathrm{c}}$ & $29.13 \pm 2.05^{\mathrm{e}}$ & 16.79 \\
\hline & & 100 & $13.60 \pm 0.05^{\mathrm{bc}}$ & $82.07 \pm 1.54^{\mathrm{c}}$ & $5.50 \pm 0.75^{\mathrm{c}}$ & $30.78 \pm 0.77^{\mathrm{e}}$ & 17.33 \\
\hline & & 120 & $13.87 \pm 0.43^{\mathrm{bc}}$ & $82.73 \pm 1.57^{\mathrm{c}}$ & $5.01 \pm 0.68^{c}$ & $28.82 \pm 1.51^{\mathrm{de}}$ & 15.04 \\
\hline & \multirow{3}{*}{10.0} & 80 & $23.32 \pm 0.92^{\mathrm{d}}$ & $77.82 \pm 3.53^{\mathrm{bc}}$ & $9.45 \pm 0.82^{\mathrm{e}}$ & $27.96 \pm 1.55^{\mathrm{de}}$ & 18.71 \\
\hline & & 100 & $23.69 \pm 0.65^{\mathrm{d}}$ & $79.31 \pm 3.39^{\mathrm{bc}}$ & $8.84 \pm 1.77^{\mathrm{d}}$ & $28.31 \pm 1.94^{\mathrm{de}}$ & 17.68 \\
\hline & & 120 & $24.83 \pm 0.49^{\mathrm{e}}$ & $77.70 \pm 3.94^{\mathrm{bc}}$ & $8.81 \pm 1.16^{\mathrm{d}}$ & $28.61 \pm 1.52^{\mathrm{de}}$ & 18.58 \\
\hline & \multirow{3}{*}{2.5} & 80 & $9.01 \pm 0.22^{\mathrm{ab}}$ & $85.06 \pm 0.36^{\mathrm{d}}$ & $3.26 \pm 0.32^{\mathrm{b}}$ & $17.71 \pm 0.40^{\mathrm{b}}$ & 5.15 \\
\hline \multirow{10}{*}{ Carrot } & & 100 & $9.28 \pm 0.05^{\mathrm{ab}}$ & $83.84 \pm 0.78^{\mathrm{c}}$ & $3.63 \pm 1.06^{\mathrm{b}}$ & $19.80 \pm 1.03^{\mathrm{bc}}$ & 7.26 \\
\hline & & 120 & $9.60 \pm 0.27^{\mathrm{ab}}$ & $85.21 \pm 0.18^{\mathrm{c}}$ & $3.01 \pm 0.42^{\mathrm{b}}$ & $18.08 \pm 1.61^{\mathrm{b}}$ & 5.01 \\
\hline & \multirow{3}{*}{5.0} & 80 & $9.06 \pm 0.16^{\mathrm{ab}}$ & $82.54 \pm 0.54^{\mathrm{c}}$ & $4.93 \pm 0.27^{\mathrm{bc}}$ & $20.05 \pm 0.31^{\mathrm{c}}$ & 8.85 \\
\hline & & 100 & $10.03 \pm 0.27^{\mathrm{ab}}$ & $83.01 \pm 1.27^{\mathrm{c}}$ & $4.25 \pm 0.76^{\mathrm{bc}}$ & $19.48 \pm 0.53^{\mathrm{bc}}$ & 7.92 \\
\hline & & 120 & $10.68 \pm 0.59^{\mathrm{ab}}$ & $84.26 \pm 1.22^{\mathrm{cd}}$ & $3.89 \pm 0.31^{\mathrm{b}}$ & $18.64 \pm 0.57^{b}$ & 6.20 \\
\hline & \multirow{3}{*}{7.5} & 80 & $14.68 \pm 0.27^{\mathrm{c}}$ & $82.39 \pm 1.37^{\mathrm{c}}$ & $5.35 \pm 0.23^{\mathrm{c}}$ & $22.79 \pm 0.34^{\mathrm{cd}}$ & 10.63 \\
\hline & & 100 & $14.35 \pm 0.27^{\mathrm{c}}$ & $83.21 \pm 1.82^{\mathrm{c}}$ & $5.59 \pm 0.23^{\mathrm{c}}$ & $23.11 \pm 0.20^{\mathrm{cd}}$ & 10.45 \\
\hline & & 120 & $14.03 \pm 0.05^{\mathrm{c}}$ & $81.62 \pm 1.70^{\mathrm{c}}$ & $5.17 \pm 1.34^{\mathrm{c}}$ & $22.05 \pm 1.28^{\mathrm{cd}}$ & 10.49 \\
\hline & \multirow{3}{*}{10.0} & 80 & $22.18 \pm 0.32^{\mathrm{d}}$ & $79.93 \pm 1.02^{\mathrm{bc}}$ & $5.11 \pm 1.19^{\mathrm{c}}$ & $24.67 \pm 0.65^{\mathrm{d}}$ & 13.73 \\
\hline & & 100 & $23.80 \pm 1.35^{\mathrm{d}}$ & $77.09 \pm 1.27^{\mathrm{bc}}$ & $5.91 \pm 0.85^{\mathrm{c}}$ & $24.26 \pm 1.12^{\mathrm{d}}$ & 15.65 \\
\hline \multirow{13}{*}{ Kale } & & 120 & $23.26 \pm 1.08^{\mathrm{d}}$ & $80.63 \pm 2.64^{\mathrm{c}}$ & $4.18 \pm 0.31^{\mathrm{bc}}$ & $23.96 \pm 0.41^{\mathrm{cd}}$ & 12.31 \\
\hline & \multirow{3}{*}{2.5} & 80 & $8.84 \pm 0.05^{\mathrm{a}}$ & $80.43 \pm 2.78^{c}$ & $1.95 \pm 0.67^{\mathrm{a}}$ & $14.84 \pm 1.01^{\mathrm{a}}$ & 9.01 \\
\hline & & 100 & $9.38 \pm 0.16^{\mathrm{a}}$ & $79.54 \pm 0.98^{\mathrm{bc}}$ & $2.17 \pm 0.65^{\mathrm{ab}}$ & $15.63 \pm 1.02^{\mathrm{ab}}$ & 9.97 \\
\hline & & 120 & $8.68 \pm 0.43^{\mathrm{a}}$ & $79.79 \pm 2.39^{\mathrm{bc}}$ & $2.08 \pm 0.81^{\mathrm{ab}}$ & $13.38 \pm 1.32^{\mathrm{a}}$ & 10.05 \\
\hline & \multirow{4}{*}{5.0} & 80 & $10.84 \pm 0.11^{\mathrm{ab}}$ & $78.08 \pm 2.78^{\mathrm{bc}}$ & $1.87 \pm 0.73^{\mathrm{a}}$ & $17.19 \pm 1.34^{\mathrm{b}}$ & 11.53 \\
\hline & & 100 & $10.90 \pm 0.16^{\mathrm{ab}}$ & $78.28 \pm 2.94^{\mathrm{bc}}$ & $1.81 \pm 0.54^{\mathrm{a}}$ & $15.10 \pm 1.52^{\mathrm{ab}}$ & 11.24 \\
\hline & & 120 & $11.17 \pm 0.32^{b}$ & $78.94 \pm 0.77^{\mathrm{bc}}$ & $1.60 \pm 0.63^{\mathrm{a}}$ & $15.71 \pm 0.81^{\mathrm{ab}}$ & 10.70 \\
\hline & & 80 & $11.81 \pm 0.22^{\mathrm{b}}$ & $75.69 \pm 1.26^{\mathrm{b}}$ & $1.96 \pm 0.61^{\mathrm{a}}$ & $16.55 \pm 0.96^{\mathrm{ab}}$ & 14.70 \\
\hline & \multirow[t]{2}{*}{7.5} & 100 & $11.60 \pm 0.43^{b}$ & $76.63 \pm 1.15^{\mathrm{b}}$ & $1.93 \pm 0.56^{\mathrm{a}}$ & $16.60 \pm 0.99^{\mathrm{ab}}$ & 13.54 \\
\hline & & 120 & $11.33 \pm 0.06^{\mathrm{b}}$ & $74.70 \pm 12.02^{\mathrm{ab}}$ & $2.07 \pm 0.60^{\mathrm{ab}}$ & $18.97 \pm 0.85^{\mathrm{b}}$ & 15.05 \\
\hline & \multirow{3}{*}{10.0} & 80 & $12.03 \pm 0.54^{\mathrm{b}}$ & $71.09 \pm 0.67^{\mathrm{a}}$ & $1.47 \pm 0.50^{\mathrm{a}}$ & $20.37 \pm 0.32^{b c}$ & 18.39 \\
\hline & & 100 & $13.70 \pm 0.49^{\mathrm{bc}}$ & $73.11 \pm 2.62^{\mathrm{a}}$ & $1.36 \pm 1.54^{\mathrm{a}}$ & $19.57 \pm 0.38^{\mathrm{bc}}$ & 16.44 \\
\hline & & 120 & $14.03 \pm 0.38^{\mathrm{bc}}$ & $72.68 \pm 3.27^{\mathrm{a}}$ & $1.87 \pm 0.65^{\mathrm{a}}$ & $17.82 \pm 1.87^{\mathrm{b}}$ & 17.23 \\
\hline
\end{tabular}

TPC - total phenolics content; L* - lightness; $a^{*}$ - balance between redness $(+)$ and greenness $(-)$; $b^{*}-$ balance between yellowness $(+)$ and blueness $(-) ; \Delta \mathrm{E}-$ total colour change index; ${ }^{\mathrm{a}-\mathrm{e}}$ - means indicated with similar letters in columns do not differ significantly at $\alpha=0.05$. 
Table 1. Contninuation

\begin{tabular}{|c|c|c|c|c|c|c|c|}
\hline \multirow{2}{*}{$\begin{array}{l}\text { Vegetable } \\
\text { type }\end{array}$} & \multirow{2}{*}{$\begin{array}{c}\text { Additive } \\
\text { amount (\%) }\end{array}$} & \multirow{2}{*}{$\begin{array}{l}\text { Screw } \\
\text { speed } \\
(\mathrm{rpm})\end{array}$} & \multirow{2}{*}{$\begin{array}{c}\text { TPC } \\
\left(\mathrm{mg} \mathrm{GAE} 100 \mathrm{~g}^{-1}\right)\end{array}$} & \multicolumn{4}{|c|}{ Colour profile } \\
\hline & & & & $\mathrm{L}^{*}$ & $a^{*}$ & $b^{*}$ & $\Delta \mathrm{E}$ \\
\hline \multirow{12}{*}{ Leek } & \multirow{3}{*}{2.5} & 80 & $9.28 \pm 0.16^{\mathrm{a}}$ & $85.22 \pm 0.12^{\mathrm{d}}$ & $2.60 \pm 0.38^{\mathrm{ab}}$ & $15.10 \pm 0.30^{\mathrm{ab}}$ & 4.22 \\
\hline & & 100 & $8.95 \pm 0.05^{\mathrm{a}}$ & $84.65 \pm 0.66^{\mathrm{cd}}$ & $3.32 \pm 0.35^{\mathrm{b}}$ & $14.88 \pm 0.32^{\mathrm{a}}$ & 5.02 \\
\hline & & 120 & $9.49 \pm 0.27^{\mathrm{a}}$ & $84.86 \pm 0.48^{\mathrm{cd}}$ & $3.97 \pm 0.55^{\mathrm{b}}$ & $15.58 \pm 0.37^{\mathrm{ab}}$ & 4.82 \\
\hline & \multirow{3}{*}{5.0} & 80 & $10.03 \pm 0.27^{\mathrm{ab}}$ & $85.90 \pm 1.09^{\mathrm{d}}$ & $2.69 \pm 0.78^{\mathrm{ab}}$ & $16.78 \pm 0.53^{\mathrm{ab}}$ & 3.90 \\
\hline & & 100 & $10.52 \pm 0.22^{\mathrm{ab}}$ & $85.54 \pm 1.83^{\mathrm{d}}$ & $3.69 \pm 0.41^{\mathrm{b}}$ & $15.92 \pm 0.49^{\mathrm{ab}}$ & 6.52 \\
\hline & & 120 & $10.30 \pm 0.11^{\mathrm{ab}}$ & $84.09 \pm 0.61^{\mathrm{cd}}$ & $3.30 \pm 0.35^{\mathrm{b}}$ & $15.43 \pm 0.62^{\mathrm{ab}}$ & 5.49 \\
\hline & \multirow{3}{*}{7.5} & 80 & $11.76 \pm 0.27^{\mathrm{b}}$ & $84.31 \pm 0.51^{\mathrm{cd}}$ & $3.57 \pm 0.40^{\mathrm{b}}$ & $15.80 \pm 0.26^{\mathrm{ab}}$ & 5.32 \\
\hline & & 100 & $11.44 \pm 0.16^{\mathrm{b}}$ & $84.66 \pm 1.61^{\mathrm{cd}}$ & $4.14 \pm 0.63^{b c}$ & $19.66 \pm 0.56^{\mathrm{bc}}$ & 8.45 \\
\hline & & 120 & $11.81 \pm 0.43^{\mathrm{b}}$ & $85.50 \pm 1.79^{d}$ & $2.90 \pm 0.82^{\mathrm{ab}}$ & $17.70 \pm 1.38^{\mathrm{b}}$ & 4.58 \\
\hline & \multirow{3}{*}{10.0} & 80 & $13.87 \pm 0.32^{\mathrm{bc}}$ & $82.24 \pm 3.92^{\mathrm{c}}$ & $3.68 \pm 0.44^{\mathrm{b}}$ & $16.33 \pm 1.95^{\mathrm{ab}}$ & 7.42 \\
\hline & & 100 & $13.88 \pm 0.97^{\mathrm{bc}}$ & $83.90 \pm 3.22^{c}$ & $3.21 \pm 0.78^{\mathrm{b}}$ & $16.34 \pm 0.71^{\mathrm{ab}}$ & 5.74 \\
\hline & & 120 & $14.41 \pm 0.86^{\mathrm{c}}$ & $82.75 \pm 0.79^{c}$ & $3.92 \pm 0.71^{\mathrm{b}}$ & $15.62 \pm 0.71^{\mathrm{ab}}$ & 6.89 \\
\hline \multirow{12}{*}{ Onion } & \multirow{3}{*}{2.5} & 80 & $9.01 \pm 0.22^{\mathrm{a}}$ & $85.85 \pm 0.59^{d}$ & $3.52 \pm 0.37^{\mathrm{b}}$ & $16.33 \pm 0.27^{\mathrm{ab}}$ & 3.97 \\
\hline & & 100 & $9.22 \pm 0.11^{\mathrm{a}}$ & $86.17 \pm 1.39^{d}$ & $3.41 \pm 0.28^{\mathrm{b}}$ & $15.87 \pm 0.53^{\mathrm{ab}}$ & 3.57 \\
\hline & & 120 & $9.33 \pm 0.11^{\mathrm{a}}$ & $85.11 \pm 1.58^{\mathrm{d}}$ & $4.47 \pm 0.70^{\mathrm{bc}}$ & $15.49 \pm 1.22^{\mathrm{ab}}$ & 4.72 \\
\hline & \multirow{3}{*}{5.0} & 80 & $9.76 \pm 0.11^{\mathrm{a}}$ & $85.62 \pm 1.17^{\mathrm{d}}$ & $2.84 \pm 0.66^{\mathrm{ab}}$ & $16.09 \pm 0.50^{\mathrm{ab}}$ & 3.96 \\
\hline & & 100 & $9.65 \pm 0.22^{\mathrm{a}}$ & $85.73 \pm 2.31^{\mathrm{d}}$ & $2.88 \pm 0.27^{\mathrm{ab}}$ & $16.00 \pm 0.72^{\mathrm{ab}}$ & 3.87 \\
\hline & & 120 & $9.28 \pm 0.27^{\mathrm{a}}$ & $83.92 \pm 3.72^{\mathrm{c}}$ & $4.14 \pm 1.24^{\mathrm{bc}}$ & $15.90 \pm 2.59^{\mathrm{ab}}$ & 5.79 \\
\hline & \multirow{3}{*}{7.5} & 80 & $9.60 \pm 0.27^{\mathrm{a}}$ & $84.69 \pm 1.29^{\mathrm{cd}}$ & $3.96 \pm 0.59^{\mathrm{b}}$ & $17.24 \pm 0.93^{\mathrm{b}}$ & 5.44 \\
\hline & & 100 & $10.14 \pm 0.11^{\mathrm{ab}}$ & $82.30 \pm 3.98^{c}$ & $4.67 \pm 0.59^{\mathrm{bc}}$ & $16.74 \pm 0.97^{\mathrm{ab}}$ & 3.94 \\
\hline & & 120 & $10.19 \pm 0.16^{\mathrm{ab}}$ & $84.84 \pm 1.71^{\mathrm{cd}}$ & $3.37 \pm 0.55^{\mathrm{b}}$ & $16.61 \pm 0.72^{\mathrm{ab}}$ & 1.39 \\
\hline & \multirow{3}{*}{10.0} & 80 & $11.33 \pm 0.16^{\mathrm{b}}$ & $84.86 \pm 1.62^{\mathrm{cd}}$ & $3.19 \pm 0.49^{b}$ & $16.68 \pm 0.70^{\mathrm{ab}}$ & 0.97 \\
\hline & & 100 & $11.00 \pm 0.27^{\mathrm{b}}$ & $82.55 \pm 1.03^{c}$ & $3.57 \pm 0.60^{\mathrm{b}}$ & $17.19 \pm 1.12^{\mathrm{b}}$ & 1.21 \\
\hline & & 120 & $11.17 \pm 0.22^{b}$ & $84.33 \pm 1.52^{\mathrm{cd}}$ & $3.16 \pm 0.81^{\mathrm{b}}$ & $16.13 \pm 0.37^{\mathrm{ab}}$ & 0.53 \\
\hline
\end{tabular}

TPC - total phenolics content; L* - lightness; $\mathrm{a}^{*}$ - balance between redness $(+)$ and greenness $(-)$; $\mathrm{b}^{*}$ - balance between yellowness $(+)$ and blueness $(-) ; \Delta \mathrm{E}$ - total colour change index; ${ }^{\mathrm{a}-\mathrm{e}}$ - means indicated with similar letters in columns do not differ significantly at $\alpha=0.05$.

observed for the snack product with a $7.5 \%(\mathrm{w} / \mathrm{w})$ addition of onion pulp for a recipe produced at $120 \mathrm{rpm}$ (Fig. 1e). The minimum value was noted for extrudates with $10.0 \%$ (w/w) carrot pulp addition produced at $80 \mathrm{rpm}$ (Fig. 1b). Thus, increasing the screw speed had the effect of increasing the process efficiency of the production of snack products enriched with fresh vegetable pulp, but the results were dependent on vegetable type. Kręcisz (2016) also noted that during the extrusion-cooking of instant corn gruels and corn-rice blends that $\mathrm{Q}$ increased along with the increase in the rotational speed of the extruder screw. Additionally, in our study, the screw speed showed a significant effect on $\mathrm{Q}$, which is comparable to the interaction effect of the content of vegetable pulp additives and screw speed for the same batches for all snack products, except for extrudates with an onion pulp. The amount of vegetable pulp added as a single variable only had a significant effect on $Q$ for snacks after the addition of beetroot and carrot pulp (Table 2). This effect was similar to the study of Lisiecka and Wójtowicz (2020), who, when adding fresh vegetable pulp to potato-based snack pellets, noted a decrease in the process efficiency with an increase in the additive content. This outcome was caused by an increasing amount of fibrous fractions originating from the fresh pulp rather than starch. In all likelihood, the increased content of vegetables may change the viscosity of the treated material and thereby influence the processing efficiency.

The specific mechanical energy calculated per $\mathrm{kg}$ of the obtained snack product increased with the increase in applied screw speed during the extrusion-cooking of snack products with beetroot, carrot and leek pulp - up to $100 \mathrm{rpm}$, but if kale or onion pulp was added, the SME decreased slightly at $120 \mathrm{rpm}$. This could be the effect of the lowest content of total carbohydrates in onion and kale, as compared with the other vegetables used in the experiment (Kunachowicz et al., 2017), and thus the lower energy 
Table 2. Results of analysis of variance of the effect of screw speed, additive type and interactions on phenolics content, processing characteristics and physical properties of rice-based supplemented crisps

\begin{tabular}{|c|c|c|c|c|c|c|c|c|c|c|}
\hline $\begin{array}{l}\text { Independent } \\
\text { variable }\end{array}$ & $\begin{array}{l}\text { Additive } \\
\text { type }\end{array}$ & $\begin{array}{l}\text { Dependent } \\
\text { variable }\end{array}$ & $\begin{array}{c}\text { Sum of } \\
\text { squares } \\
\text { effect }\end{array}$ & df effect & $\begin{array}{c}\text { Mean } \\
\text { square } \\
\text { effect }\end{array}$ & $\begin{array}{l}\text { Sum of } \\
\text { squares } \\
\text { error }\end{array}$ & df error & $\begin{array}{c}\text { Mean } \\
\text { square } \\
\text { error }\end{array}$ & F-test & $p$ value \\
\hline \multirow{25}{*}{$\begin{array}{l}\text { Content of } \\
\text { additive } \\
(\%)\end{array}$} & \multirow{5}{*}{ Beetroot } & TPC & 807.6 & 4 & 201.9 & 13.00 & 25 & 0.520 & 388.3 & $0.000^{\dagger}$ \\
\hline & & Q & 166.7 & 4 & 41.68 & 181.4 & 25 & 7.200 & 5.750 & $0.002^{\dagger}$ \\
\hline & & SEM & 0.028 & 4 & 0.007 & 0.089 & 25 & 0.004 & 1.980 & 0.129 \\
\hline & & ER & 10.29 & 4 & 2.571 & 7.982 & 145 & 0.055 & 46.71 & $0.000^{\dagger}$ \\
\hline & & $\mathrm{BD}$ & 80004 & 4 & 20001 & 8438 & 70 & 120.6 & 166.0 & $0.000^{\dagger}$ \\
\hline & \multirow{5}{*}{ Carrot } & TPC & 948.7 & 4 & 237.2 & 20.84 & 25 & 0.830 & 284.5 & $0.000^{\dagger}$ \\
\hline & & $\mathrm{Q}$ & 172.1 & 4 & 43.03 & 219.8 & 25 & 58.79 & 4.890 & $0.005^{\dagger}$ \\
\hline & & SEM & 0.028 & 4 & 0.007 & 0.085 & 25 & 0.003 & 2.050 & 0.118 \\
\hline & & ER & 12.01 & 4 & 3.003 & 7.641 & 145 & 0.053 & 56.99 & $0.000^{\dagger}$ \\
\hline & & $\mathrm{BD}$ & 96628 & 4 & 24157 & 5855 & 70 & 83.64 & 288.8 & $0.000^{\dagger}$ \\
\hline & \multirow{5}{*}{ Kale } & TPC & 96.91 & 4 & 24.23 & 8.720 & 25 & 0.350 & 69.50 & $0.000^{\dagger}$ \\
\hline & & $\mathrm{Q}$ & 87.89 & 4 & 21.97 & 310.6 & 25 & 12.42 & 1.770 & 0.167 \\
\hline & & SEM & 0.019 & 4 & 0.005 & 0.080 & 25 & 0.003 & 1.500 & 0.234 \\
\hline & & ER & 3.178 & 4 & 0.795 & 11.84 & 145 & 0.082 & 9.730 & $0.000^{\dagger}$ \\
\hline & & $\mathrm{BD}$ & 14894 & 4 & 3723 & 3859 & 70 & 55.13 & 67.54 & $0.000^{\dagger}$ \\
\hline & \multirow{5}{*}{ Leek } & TPC & 121.6 & 4 & 30.40 & 6.410 & 25 & 0.260 & 118.6 & $0.000^{\dagger}$ \\
\hline & & Q & 21.78 & 4 & 5.455 & 163.8 & 25 & 6.550 & 0.830 & 0.518 \\
\hline & & SEM & 0.007 & 4 & 0.005 & 0.090 & 25 & 0.004 & 0.457 & 0.767 \\
\hline & & ER & 5.240 & 4 & 1.310 & 7.177 & 145 & 0.049 & 26.46 & $0.000^{\dagger}$ \\
\hline & & $\mathrm{BD}$ & 5458 & 4 & 1365 & 3151 & 70 & 45.01 & 30.32 & $0.000^{\dagger}$ \\
\hline & \multirow{5}{*}{ Onion } & TPC & 26.92 & 4 & 6.730 & 2.51 & 25 & 0.100 & 66.96 & $0.000^{\dagger}$ \\
\hline & & $\mathrm{Q}$ & 141.1 & 4 & 35.27 & 763.2 & 25 & 30.53 & 1.160 & 0.354 \\
\hline & & SEM & 0.033 & 4 & 0.008 & 0.084 & 25 & 0.003 & 2.407 & 0.076 \\
\hline & & ER & 3.606 & 4 & 0.901 & 3.940 & 145 & 0.027 & 32.94 & $0.000^{\dagger}$ \\
\hline & & $\mathrm{BD}$ & 15845 & 4 & 3961 & 3130 & 70 & 44.71 & 88.60 & $0.000^{\dagger}$ \\
\hline \multirow{20}{*}{$\begin{array}{l}\text { Screw speed } \\
(\mathrm{rpm})\end{array}$} & \multirow{5}{*}{ Beetroot } & TPC & 4.140 & 2 & 2.070 & 816.5 & 27 & 30.24 & 0.070 & 0.934 \\
\hline & & $\mathrm{Q}$ & 156.6 & 2 & 78.27 & 191.5 & 27 & 7.090 & 11.03 & $0.000^{\dagger}$ \\
\hline & & SEM & 0.001 & 2 & 0.005 & 0.107 & 27 & 0.004 & 1.190 & 0.319 \\
\hline & & ER & 0.490 & 2 & 0.245 & 17.7 & 147 & 0.121 & 2.030 & 0.135 \\
\hline & & $\mathrm{BD}$ & 6698 & 2 & 3349 & 881744 & 72 & 1135 & 2.940 & 0.059 \\
\hline & \multirow{5}{*}{ Carrot } & TPC & 2.840 & 2 & 1.420 & 966.7 & 27 & 35.80 & 0.040 & 0.961 \\
\hline & & $\mathrm{Q}$ & 190.5 & 2 & 95.26 & 201.4 & 27 & 7.460 & 12.77 & $0.000^{\dagger}$ \\
\hline & & SEM & 0.006 & 2 & 0.003 & 0.108 & 27 & 0.004 & 0.696 & 0.507 \\
\hline & & ER & 1.482 & 2 & 0.741 & 18.17 & 147 & 0.124 & 6.000 & $0.003^{\dagger}$ \\
\hline & & $\mathrm{BD}$ & 2624 & 2 & 1312 & 99859 & 72 & 1387 & 0.946 & 0.393 \\
\hline & \multirow{5}{*}{ Kale } & TPC & 0.940 & 2 & 0.470 & 104.7 & 27 & 3.880 & 0.120 & 0.886 \\
\hline & & $\mathrm{Q}$ & 294.9 & 2 & 147.5 & 103.6 & 27 & 3.840 & 38.44 & $0.000^{\dagger}$ \\
\hline & & SEM & 0.001 & 2 & 0.001 & 0.097 & 27 & 0.004 & 0.172 & 0.843 \\
\hline & & ER & 0.170 & 2 & 0.085 & 14.85 & 147 & 0.101 & 0.839 & 0.434 \\
\hline & & $\mathrm{BD}$ & 2930 & 2 & 1465 & 15823 & 72 & 219.8 & 6.666 & $0.002^{\dagger}$ \\
\hline & \multirow{5}{*}{ Leek } & TPC & 0.890 & 2 & 0.450 & 127.1 & 27 & 4.710 & 0.090 & 0.910 \\
\hline & & $\mathrm{Q}$ & 143.1 & 2 & 71.54 & 42.45 & 27 & 1.570 & 45.50 & $0.000^{\dagger}$ \\
\hline & & SEM & 0.009 & 2 & 0.005 & 0.087 & 27 & 0.003 & 1.447 & 0.253 \\
\hline & & ER & 0.475 & 2 & 0.237 & 11.94 & 147 & 0.081 & 2.920 & 0.057 \\
\hline & & $\mathrm{BD}$ & 2390 & 2 & 1195 & 6220 & 72 & 86.38 & 13.83 & $0.000^{\dagger}$ \\
\hline
\end{tabular}

TPC - total phenolics content, Q - processing efficiency, SME - specific mechanical energy, ER - expansion ratio, BD - bulk density, indicates significant effect at $\alpha=0.05$. 
Table 2. Continuation

\begin{tabular}{|c|c|c|c|c|c|c|c|c|c|c|}
\hline $\begin{array}{l}\text { Independent } \\
\text { variable }\end{array}$ & $\begin{array}{l}\text { Additive } \\
\text { type }\end{array}$ & $\begin{array}{l}\text { Dependent } \\
\text { variable }\end{array}$ & $\begin{array}{c}\text { Sum of } \\
\text { squares } \\
\text { effect }\end{array}$ & $\begin{array}{c}\text { df } \\
\text { effect }\end{array}$ & $\begin{array}{c}\text { Mean } \\
\text { square } \\
\text { effect }\end{array}$ & $\begin{array}{c}\text { Sum of } \\
\text { squares } \\
\text { error }\end{array}$ & $\begin{array}{c}\text { df } \\
\text { error }\end{array}$ & $\begin{array}{l}\text { Mean } \\
\text { square } \\
\text { error }\end{array}$ & F-test & $p$ value \\
\hline \multirow{5}{*}{$\begin{array}{l}\text { Screw speed } \\
(\mathrm{rpm})\end{array}$} & \multirow{5}{*}{ Onion } & TPC & 0.130 & 2 & 0.070 & 29.300 & 27 & 1.090 & 0.060 & 0.940 \\
\hline & & Q & 116.9 & 2 & 58.47 & 787.3 & 27 & 29.16 & 2.000 & 0.154 \\
\hline & & SEM & 0.004 & 2 & 0.002 & 0.114 & 27 & 0.004 & 0.418 & 0.663 \\
\hline & & ER & 0.669 & 2 & 0.334 & 6.877 & 147 & 0.047 & 7.096 & $0.001^{\dagger}$ \\
\hline & & $\mathrm{BD}$ & 2547 & 2 & 1273 & 16428 & 72 & 228.2 & 5.581 & $0.006^{\dagger}$ \\
\hline \multirow{25}{*}{$\begin{array}{l}\text { Content of } \\
\text { the additive } \\
(\%) \\
\times \\
\text { Screw speed } \\
(\mathrm{rpm})\end{array}$} & & TPC & 815.0 & 14 & 58.21 & 5.600 & 15 & 0.370 & 156.0 & $0.000^{\dagger}$ \\
\hline & & $\mathrm{Q}$ & 346.2 & 14 & 24.73 & 1.88 & 15 & 0.130 & 197.8 & $0.000^{\dagger}$ \\
\hline & Beetroot & SEM & 0.042 & 14 & 0.003 & 0.075 & 15 & 0.005 & 0.600 & 0.827 \\
\hline & & ER & 11.62 & 14 & 0.830 & 6.650 & 135 & 0.049 & 16.85 & $0.000^{\dagger}$ \\
\hline & & $\mathrm{BD}$ & 88327 & 14 & 6309 & 115.20 & 60 & 1.920 & 3286 & $0.000^{\dagger}$ \\
\hline & & TPC & 961.8 & 14 & 68.70 & 7.71 & 15 & 0.510 & 133.6 & $0.000^{\dagger}$ \\
\hline & & $\mathrm{Q}$ & 390.0 & 14 & 27.86 & 1.88 & 15 & 0.130 & 223.0 & $0.000^{\dagger}$ \\
\hline & Carrot & SEM & 0.038 & 14 & 0.003 & 0.075 & 15 & 0.005 & 0.544 & 0.869 \\
\hline & & ER & 14.69 & 14 & 1.049 & 4.967 & 135 & 0.037 & 28.51 & $0.000^{\dagger}$ \\
\hline & & $\mathrm{BD}$ & 102387 & 14 & 7313 & 96.00 & 60 & 1.600 & 4571 & $0.000^{\dagger}$ \\
\hline & \multirow{5}{*}{ Kale } & TPC & 103.1 & 14 & 7.360 & 2.570 & 15 & 0.170 & 43.02 & $0.000^{\dagger}$ \\
\hline & & $\mathrm{Q}$ & 396.6 & 14 & 28.33 & 1.880 & 15 & 0.130 & 226.6 & $0.000^{\dagger}$ \\
\hline & & SEM & 0.024 & 14 & 0.002 & 0.075 & 15 & 0.005 & 0.336 & 0.976 \\
\hline & & ER & 4.750 & 14 & 0.339 & 10.27 & 135 & 0.076 & 4.460 & $0.000^{\dagger}$ \\
\hline & & $\mathrm{BD}$ & 18622 & 14 & 1330 & 131.2 & 60 & 2.180 & 608.3 & $0.000^{\dagger}$ \\
\hline & \multirow{5}{*}{ Leek } & $\mathrm{TPC}$ & 123.3 & 14 & 8.810 & 4.660 & 15 & 0.310 & 28.33 & $0.000^{\dagger}$ \\
\hline & & $\mathrm{Q}$ & 183.7 & 14 & 13.12 & 1.880 & 15 & 0.130 & 105.0 & $0.000^{\dagger}$ \\
\hline & & SEM & 0.021 & 14 & 0.002 & 0.075 & 15 & 0.005 & 0.302 & 0.985 \\
\hline & & ER & 6.520 & 14 & 0.466 & 5.897 & 135 & 0.043 & 10.66 & $0.000^{\dagger}$ \\
\hline & & $\mathrm{BD}$ & 8502 & 14 & 607.3 & 107.2 & 60 & 1.787 & 339.9 & $0.000^{\dagger}$ \\
\hline & \multirow{5}{*}{ Onion } & TPC & 28.49 & 14 & 2.03 & 0.95 & 15 & 0.060 & 32.11 & $0.000^{\dagger}$ \\
\hline & & Q & 535.3 & 14 & 38.24 & 369.0 & 15 & 24.60 & 1.554 & 0.203 \\
\hline & & SEM & 0.042 & 14 & 0.003 & 0.075 & 15 & 0.005 & 0.600 & 0.827 \\
\hline & & ER & 5.087 & 14 & 0.363 & 2.458 & 135 & 0.018 & 19.81 & $0.000^{\dagger}$ \\
\hline & & $\mathrm{BD}$ & 188480 & 14 & 1346 & 126.4 & 60 & 2.107 & 639.1 & $0.000^{\dagger}$ \\
\hline
\end{tabular}

TPC - total phenolics content, Q - processing efficiency, SME - specific mechanical energy, ER - expansion ratio, BD - bulk density, indicates significant effect at $\alpha=0.05$.

required for gelatinization at the highest screw speed applied during processing. Altan et al. (2008) also noted a tendency that the increase in rotational speed influenced the increase in the SME values during the extrusioncooking of barley-tomato pomace blends. Other reports explained that enhanced SME was caused by the fact that more energy is supplied from the engine to obtain higher screw rotations (Baik et al., 2004). However, in our experiments, in the case of mechanical energy requirements, independent variables were shown to have an insignificant effect on SME for all of the snack products tested (Table 2). Moreover, minimum values of SME (below $0.24 \mathrm{kWh} \mathrm{kg}^{-1}$ ) were noted during the extrusion of snacks with $2.5 \%(\mathrm{w} / \mathrm{w})$ of beetroot pulp addition that were produced at $80 \mathrm{rpm}$ (Fig. 2a), while the maximum values (over $0.36 \mathrm{kWh} \mathrm{kg}^{-1}$ ) were observed for extrudates supplemented with $5.0 \%$ (w/w) leek pulp produced at $100 \mathrm{rpm}$ (Fig. 2d). Some reports show that the SME outcome value is the result of a combination of moisture content, fibre content and pro- cessing temperature (Stojceska et al., 2009; Altan et al., 2008; Singha et al., 2018). In our study, SME results were in almost all cases traceable to a lowering of the processing energy requirements corresponding to the increased initial moisture content of the blends that contained higher amounts of fresh vegetable pulp. This effect is due to the presence of natural water in the fresh plant pulps. In addition, the application of fresh pulp eliminates the huge energy requirement of drying the vegetables before processing. As reported by Rojas et al. (2020), the energy consumption for the drying process can even reach $84-150 \mathrm{kWh} \mathrm{kg}^{-1}$, so the concept of using fresh vegetables seems to be beneficial for the industry if the quality features turn out to be acceptable. Due to the fact that single screw extrusion-cooking is a low energy consumption process, it is therefore possible to make snacks more economically efficient if fresh vegetable pulp is applied to produce supplemented ready-to-eat snacks. 

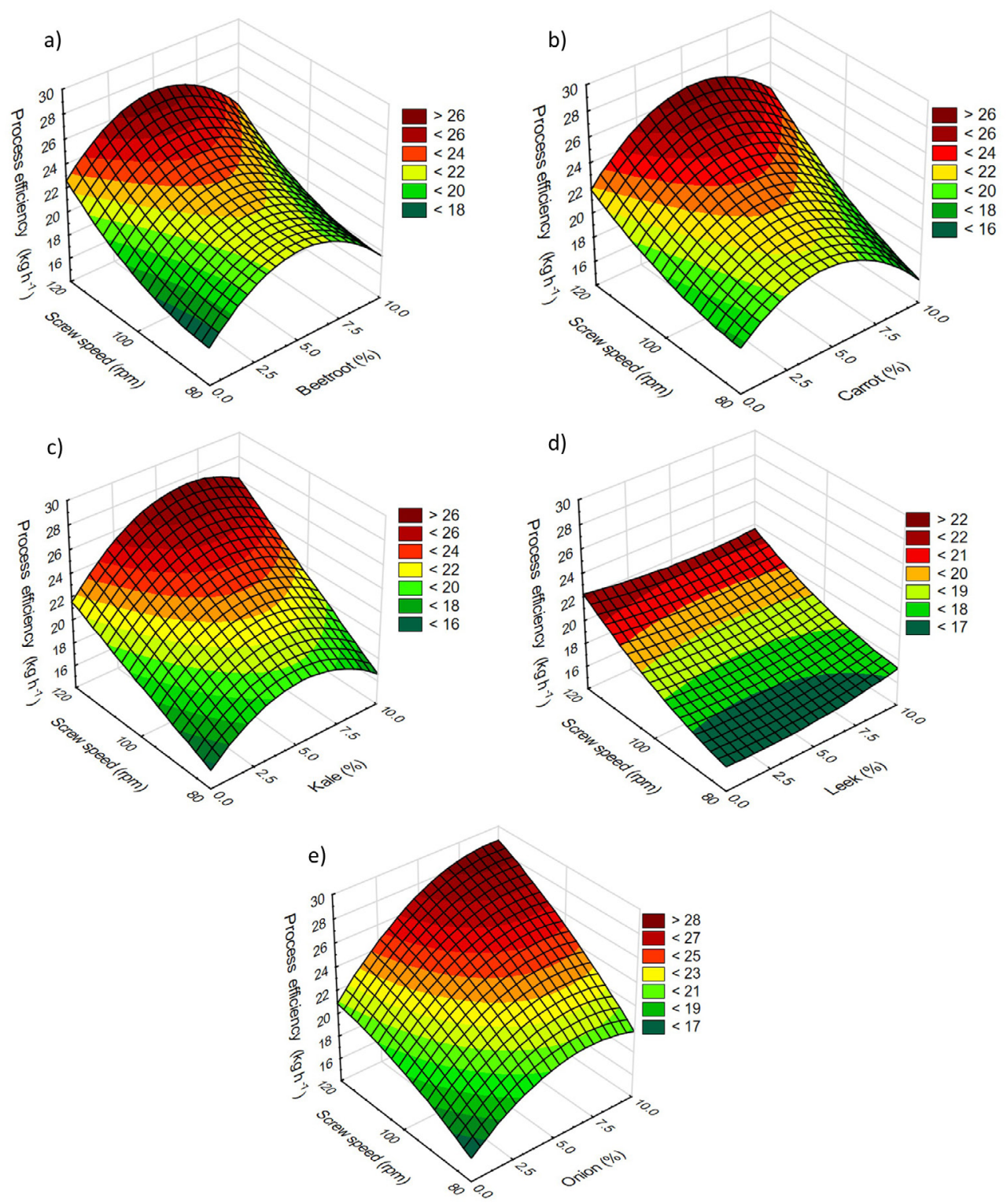

Fig. 1. Processing efficiency of rice-based snack products enriched with fresh vegetable pulps processed at various screw speeds: a) beetroot, b) carrot, c) kale, d) leek, e) onion.

The initial moisture content of the rice flour was $13.10 \%$ and the prepared blends were characterized by moisture contents that ranged from 14.10 and $14.16 \%$ - if $2.5 \%$ $(\mathrm{w} / \mathrm{w})$ of kale and carrot pulps were used in the blends, respectively. This increased to $21.02 \%$ for the blend with $10.0 \%(\mathrm{w} / \mathrm{w})$ beetroot pulp. Kale and carrot were characterized by low pulp initial moisture content, whereas beetroot pulp had highest values. In general, the moisture content of the blend increased with increasing amounts of fresh ingredients in the recipe, which was expected. However, the final moisture content of the snack products did not exceed $13 \%$, and the differences between the samples were not significant. The moisture contents of the ready-to-eat supplemented snacks were similar to those of the control rice sample (mean $\mathrm{MC}$ of $11.90 \%$ ) and depending on the type of vegetable pulp used, showed MC values of 12.10$12.87 \%$ if beetroot was applied, $10.89-12.19 \%$ when carrot was added, $11.41-12.32 \%$ for kale addition, $10.46-11.36 \%$ if leek was used, and $10.31-11.80 \%$ for onion application. The water activity WA of the snacks ranged from 0.50 for the control rice snack products, to 0.55 for snack products with $10.0 \%(\mathrm{w} / \mathrm{w})$ beetroot or carrot pulp addition. These values of WA were not significantly different and were also stable - thereby ensuring microbiological safety during the storage of snacks.

A high degree of expansion is a desirable feature in directly expanded snack products (Poliszko et al., 2019; Shah et al., 2017). The highest expansion ratio was found for snack products supplemented with $5.0 \%(\mathrm{w} / \mathrm{w})$ of kale pulp produced at $120 \mathrm{rpm}$ (Fig. 3c). In contrast, the lowest 

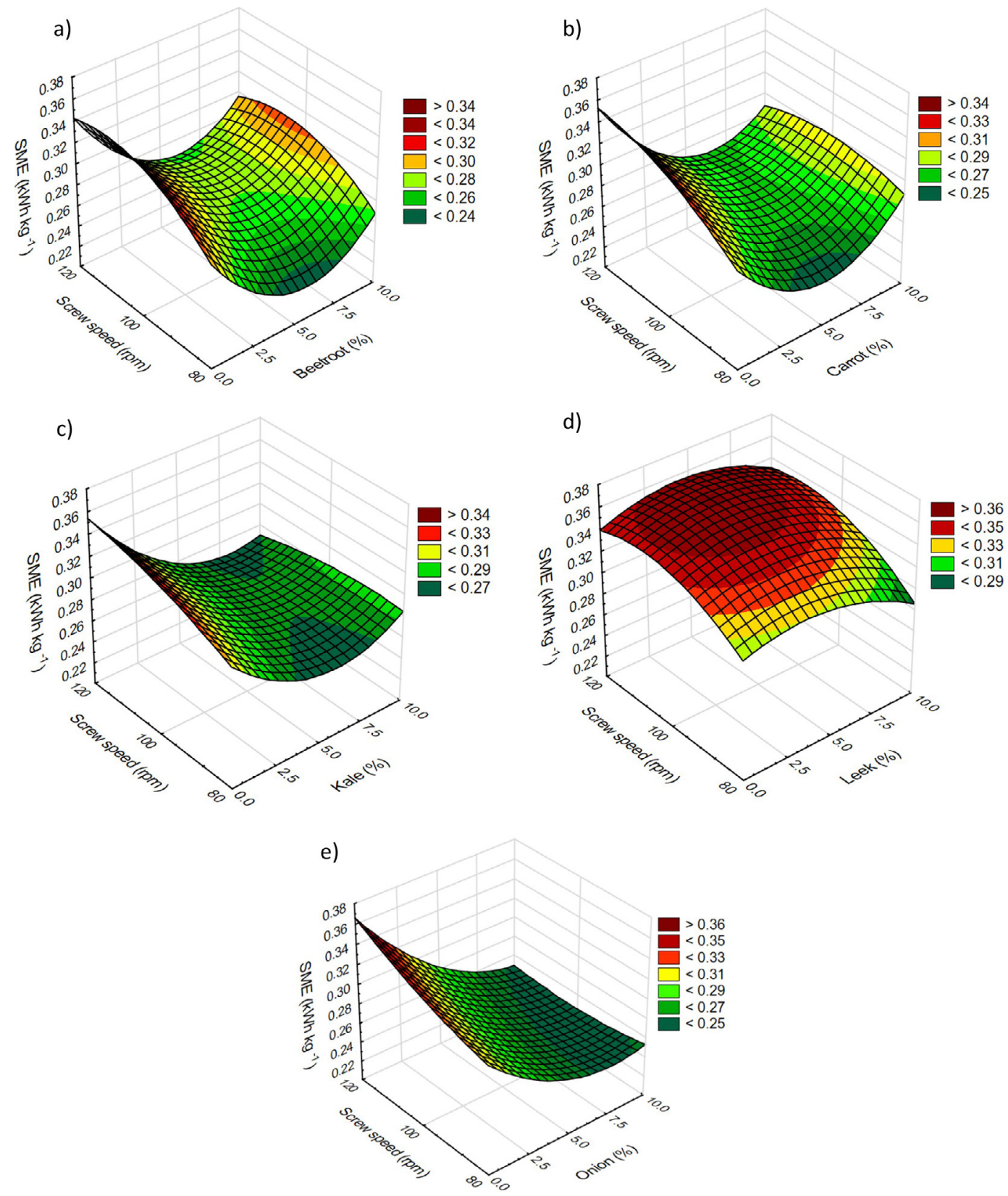

Fig. 2. SME of rice-based snack items enriched with fresh vegetable pulps processed at various screw speeds: a) beetroot, b) carrot, c) kale, d) leek, e) onion.

expansion ratio was noted for snack products enriched with $10.0 \%(\mathrm{w} / \mathrm{w})$ of carrot pulp in the recipe extruded at $80 \mathrm{rpm}$ (Fig. 3b). The ER of the extruded snack products decreased in inverse proportion to the higher additive levels in relation to the control rice snack product, especially when beetroot, carrot, leek or onion pulp were applied (Fig. 3a, b, d, e). A similar relationship was observed for corn extrudates with the addition of dried tomatoes (Wójtowicz et al., 2018). In this case, the effect was attributed to the decreasing amount of starch in favour of the additive, which made it difficult to obtain the porous structure characteristic of expanded snack products. In similar work, the addition of bean flour to corn snack products led to a significant decrease in the expansion of extrudates, because of the interactions between the increased concentrations of protein and fibre (Anton et al., 2009). In other work, it was found that the high content of dietary fibre from dry herbal plants decreased the expansion of corn snack products supplemented with Moldavian dragonhead (Wójtowicz et al., 2017). The limited expansion of snack products supplemented with fresh vegetable pulp could be the result of the integrated impact of water from plant pulps, as well as decreased starch content due to replacement by vegetable matter. It could also be caused by the increased water content resulting from the addition 

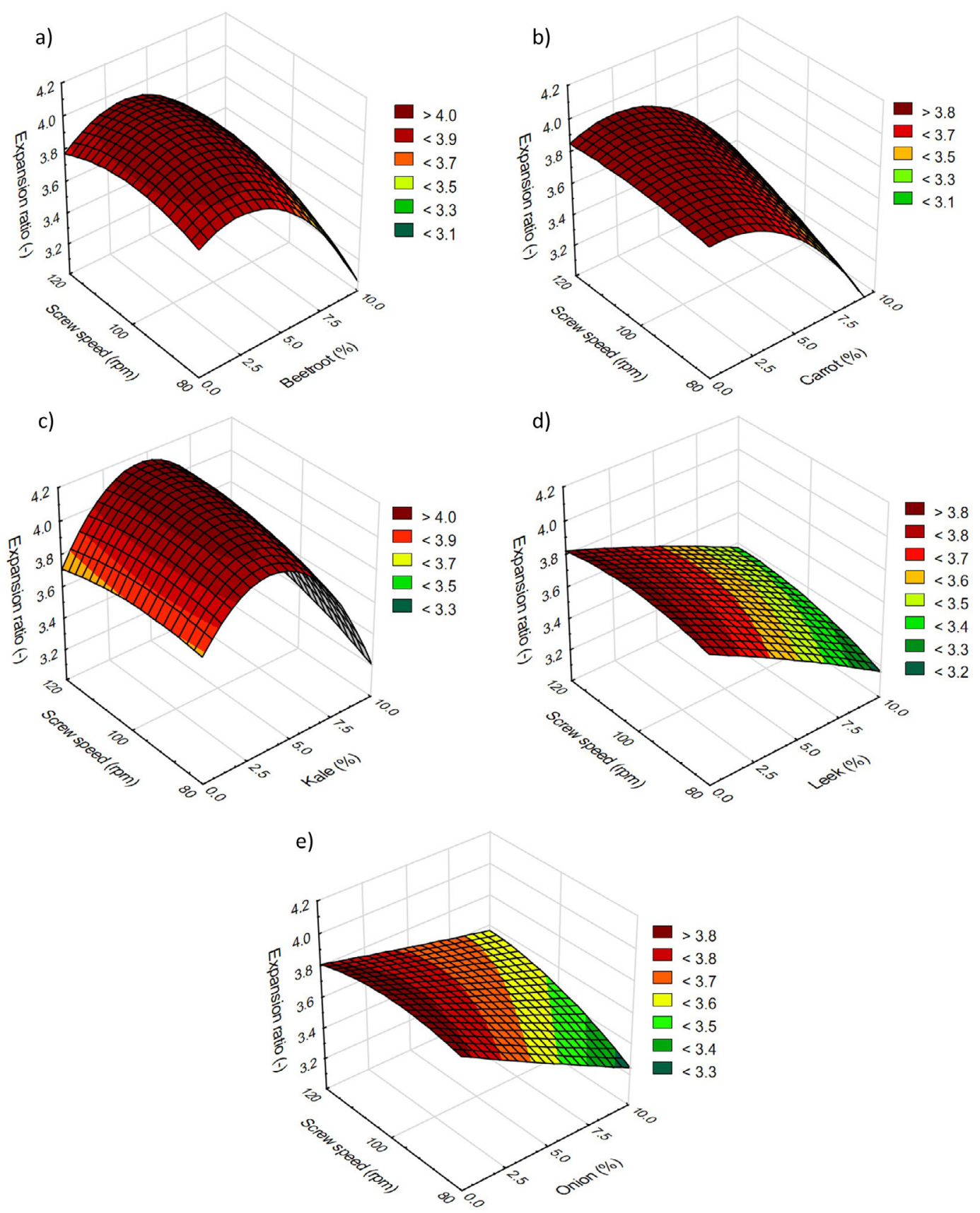

Fig. 3. ER of rice-based snack products enriched with fresh vegetable pulps processed at various screw speeds: a) beetroot, b) carrot, c) kale, d) leek, e) onion.

of fresh vegetable components. Indeed, we noted that the amount of vegetable additives added had significant effects on ER for all of the snack products. This effect was proportionally similar to the interactions of the content of vegetable additives and screw speeds that occurred in the same batches. As a single variable, the screw speed had a significant effect on ER (Table 2), but only in the case of extrudates supplemented with carrot or onion pulp - which showed the lowest MC in fresh pulp.
According to Lucas et al. (2018), an item's bulk density is a measure of its multi-directional expansion and this factor presents the possibility of evaluating the quality of directly expanded extrudates. In the present study, the addition of fresh vegetable pulps and the application of the lowest screw speeds during processing brought about the increased BD of extrudates (Fig. 4). The same phenomenon was observed for extrudates developed from food by-products (Yağc1 and Göğüș, 2008). We also recorded the 

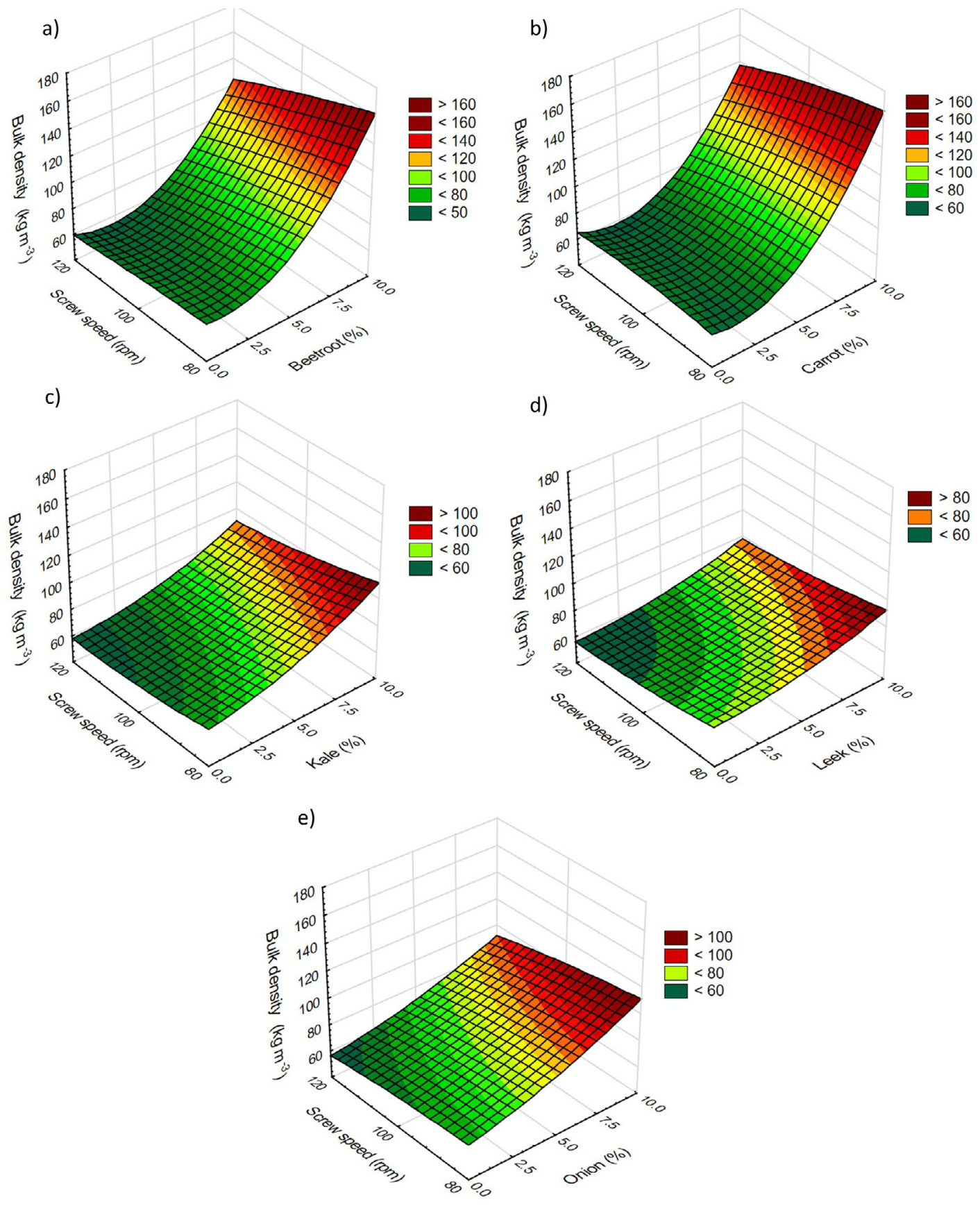

Fig. 4. BD of rice-based snack products enriched with fresh vegetable pulps and processed at various screw speeds: a) beetroot, b) carrot, c) kale, d) leek, e) onion.

highest BD $\left(166.03 \mathrm{~kg} \mathrm{~m}^{-3}\right)$ for extrudates supplemented with $10.0 \%(\mathrm{w} / \mathrm{w})$ carrot pulp addition processed at a screw speed of $80 \mathrm{rpm}$ (Fig. 4b), while the lowest $\left(48.96 \mathrm{~kg} \mathrm{~m}^{-3}\right)$ was observed for rice snack products enriched with $2.5 \%$ $(\mathrm{w} / \mathrm{w})$ beetroot pulp addition when processed at $120 \mathrm{rpm}$ (Fig. 4a). Previous research has shown that low moisture content, high screw speed and high barrel temperatures produce a low density, this combination is typical for expanded products (Meng et al., 2010; Wójtowicz et al., 2015; Chen et al., 2020; Lv et al., 2018). High temperatures, which occur e.g. during the baking of gluten-free products supplemented with vegetables also affect the conformation changes in products (Drabinska et al., 2018). In our work, however, the results of the analysis of variance concerning the effect of processing conditions and blends composition on $\mathrm{BD}$ showed that the screw speed as a single variable had a significant effect on BD only in the case of extrudates with kale, leek or onion pulp (Table 2). 
Colour is a very important feature, because it provides information about changes that have occurred in the product during processing (Darvishi et al., 2014; Krishnaraj et al., 2019). The colour profile evaluated via the CIE-Lab scale indicated $\mathrm{L}^{*}$ values ranging from 71.09 to 90.87 , a* values from 1.36 to 9.45 and $b^{*}$ values from 13.38 to 30.78 (Table 1). The highest values of $\mathrm{L}^{*}$ were found for the control rice snack products processed at $100 \mathrm{rpm}$. This may be related to the natural white colour of rice flour. In general terms, a decrease in lightness was observed in tandem with the increasing addition of vegetable pulps, as compared to the control rice snack products (Table 1). The most impressive changes occurred due to the type of vegetables used and their amount in the recipe as a result of increasing the amount of the additive and the decreasing proportion of rice flour. The lowest lightness was observed in snacks supplemented with kale pulp addition due to the natural dark green colour of fresh kale leaves. Low $\mathrm{L}^{*}$ values were also observed with the application of $10.0 \%(\mathrm{w} / \mathrm{w})$ beetroot or carrot pulp. Of note, insignificant differences between these values occurred despite the fact that the natural colour of beetroot and carrot is quite different (deep purple and deep orange, respectively). We also saw the highest total colour change index $\Delta \mathrm{E}$ values for these additives (indicating significant differences compared to the control sample).

The most intensive redness a* was obtained for ricebased snack products supplemented with $10.0 \%(\mathrm{w} / \mathrm{w})$ beetroot pulp extruded at $80 \mathrm{rpm}$. An intensive yellow tint $b^{*}$ was noted for snack items supplemented with $7.5 \%$ and $10.0 \%(\mathrm{w} / \mathrm{w})$ beetroot or carrot pulp due to the presence of natural pigments such as the betalains responsible for the typical red colour of beetroot or the carotenoids that produce the yellow-orange colour of carrot. Because kale is a vegetable with a relatively high content of green chlorophyll pigments, low values of $\mathrm{a}^{*}$, visually close to a green tint, were indicated for snacks supplemented with 5.0$10.0 \%(\mathrm{w} / \mathrm{w})$ kale pulp (Table 1).

Due to the type of vegetable used, no significant differences in $\mathrm{L}^{*}$ values were found between the extrudates enriched with beetroot and carrot or between leek and onion (Table 1), while the amount of vegetable additives used had significant effects on the $L^{*}, a^{*}$ and $b^{*}$ values of all of the tested snack products. $\Delta \mathrm{E}$ values were at their lowest point (below 5) if onion pulp was applied as an additive, especially if $10.0 \%(\mathrm{w} / \mathrm{w})$ was used, because of the natural light yellow colour similar to rice flour, indicating the insignificant differences visually observed in the colour of the snacks between the control rice snacks and the onion enriched puffs. The screw speed only had a significant effect on $a^{*}$ and $b^{*}$ colour coordinates in snack products with the addition of fresh leek pulp (Table 3). However, interactions between independent variables significantly affected the $a^{*}$ values of all snack products, except for the extrudates supplemented with kale pulp.
Hardness is a peak force that is linked with ER, because less expanded snack products with a higher density tend to be harder (Hashemi et al., 2017; Shah et al., 2017). Maximum $\mathrm{H}(534 \mathrm{~N})$ was found during the testing of rice snack products supplemented with $7.5 \%(\mathrm{w} / \mathrm{w})$ leek pulp processed at $80 \mathrm{rpm}$, while the lowest values (328.5 and $348.0 \mathrm{~N}$ ) were evidensed for rice based snacks with the addition of $10.0 \%(\mathrm{w} / \mathrm{w})$ onion pulp extruded at 100 and $120 \mathrm{rpm}$, respectively. In general, a decrease in $\mathrm{H}$ was observed for all snack products supplemented with fresh vegetable pulp in relation to the control rice snack items when $80 \mathrm{rpm}$ was applied during processing (Table 4). In addition, additives in amounts above $5.0 \%(\mathrm{w} / \mathrm{w})$ resulted in significant changes to snack product hardness. This may be attributed to an increase in the initial moisture content of processed raw materials due to the presence of higher amounts of water originating from fresh vegatable pulps and a lower expansion of the snacks. At the same time, there were significant differences in $\mathrm{H}$ between the snack products produced at various rpm - especially when kale, leek and onion were applied (Table 4). Moreover, interactions between the content of vegetable additives and screw speed showed significant effects in hardness with regard to all of the tested snack products. However, as a single independent variable, the amount of additive on $\mathrm{H}$ only revealed a significant effect for snacks supplemented with beetroot, carrot or onion (Table 5).

The property of a desirable level of crispness is a manifestation of the fact that extrudates are easily broken because there are many small air cells inside the sample and thus a pleasant cellular texture with a low degree of brittleness and stiffness is achieved. The lowest value of force required for the destruction of the sample indicating a favourable crispness level was observed for snacks with $2.5 \%(\mathrm{w} / \mathrm{w})$ carrot pulp extruded at $80 \mathrm{rpm}(1.82 \mathrm{~N})$, whereas the highest level was noted for snacks with a 7.5\% (w/w) application of leek or onion pulp (Table 4). The addition of beetroot and carrot pulps allowed for the achievement of crispier snacks as compared with other vegetables. No significant differences were found with regard to the type of vegetable used compared to the control snack except with the application of $2.5-5.0 \%(\mathrm{w} / \mathrm{w})$ of beetroot or carrot pulp, but the addition of vegetable pulp at a level above $7.5 \%(\mathrm{w} / \mathrm{w})$ showed significant changes in crispness due to the more compact structure, lower expansion levels and increased density of the tested snacks (Table 4).

Interactions between independent variables had a significant effect on CR only for the snacks supplemented with carrot pulp, and the amount of additives only had a significant effect if carrot or onion pulp was used (Table 5). The maximum fracturability value was noted for snack products with $2.5 \%(\mathrm{w} / \mathrm{w})$ kale pulp in the recipe, and when the snacks were produced at $120 \mathrm{rpm}$. The amount of additive alone had a significant effect on FR for snacks supplemented with beetroot pulp (Table 5). Generally, the 
Table 3. Results of analysis of variance of the effect of screw speed, additive type and interactions on colour profile of rice-based supplemented crisps

\begin{tabular}{|c|c|c|c|c|c|c|c|c|c|c|}
\hline $\begin{array}{l}\text { Independent } \\
\text { variable }\end{array}$ & $\begin{array}{l}\text { Additive } \\
\text { type }\end{array}$ & $\begin{array}{l}\text { Dependent } \\
\text { variable }\end{array}$ & $\begin{array}{l}\text { Sum of } \\
\text { squares } \\
\text { effect }\end{array}$ & $\begin{array}{c}\text { df } \\
\text { effect }\end{array}$ & $\begin{array}{l}\text { Mean } \\
\text { square } \\
\text { effect }\end{array}$ & $\begin{array}{l}\text { Sum of } \\
\text { squares } \\
\text { error }\end{array}$ & $\begin{array}{l}\text { df } \\
\text { error }\end{array}$ & $\begin{array}{l}\text { Mean } \\
\text { square } \\
\text { error }\end{array}$ & F-test & $p$ values \\
\hline \multirow{15}{*}{$\begin{array}{l}\text { Content of the } \\
\text { additive }(\%)\end{array}$} & \multirow{3}{*}{ Beetroot } & $\mathrm{L}^{*}$ & 2187 & 4 & 546.8 & 696.8 & 145 & 4.81 & 113.8 & $0.000^{\dagger}$ \\
\hline & & $a^{*}$ & 885.9 & 4 & 214.0 & 152.3 & 145 & 1.05 & 203.8 & $0.000^{\dagger}$ \\
\hline & & $b^{*}$ & 4753 & 4 & 1188 & 360.5 & 145 & 2.49 & 478.0 & $0.000^{\dagger}$ \\
\hline & \multirow{3}{*}{ Carrot } & $\mathrm{L}^{*}$ & 1839 & 4 & 459.7 & 387.7 & 145 & 2.67 & 171.9 & $0.000^{\dagger}$ \\
\hline & & $a^{*}$ & 179.9 & 4 & 44.98 & 118.3 & 145 & 0.82 & 55.15 & $0.000^{\dagger}$ \\
\hline & & $b^{*}$ & 1469 & 4 & 367.3 & 164.2 & 145 & 1.14 & 323.6 & $0.000^{\dagger}$ \\
\hline & \multirow{3}{*}{ Kale } & $\mathrm{L}^{*}$ & 5291 & 4 & 1323 & 730.2 & 145 & 5.04 & 262.7 & $0.000^{\dagger}$ \\
\hline & & $a^{*}$ & 13.21 & 4 & 3.300 & 113.0 & 145 & 0.78 & 4.240 & $0.003^{\dagger}$ \\
\hline & & $b^{*}$ & 339.1 & 4 & 99.77 & 335.1 & 145 & 2.31 & 43.17 & $0.000^{\dagger}$ \\
\hline & \multirow{3}{*}{ Leek } & $\mathrm{L}^{*}$ & 881.1 & 4 & 220.3 & 540.6 & 145 & 3.73 & 59.09 & $0.000^{\dagger}$ \\
\hline & & $a^{*}$ & 24.27 & 4 & 6.070 & 111.5 & 145 & 0.77 & 7.890 & $0.000^{\dagger}$ \\
\hline & & $b^{*}$ & 181.3 & 4 & 45.32 & 283.2 & 145 & 1.95 & 23.20 & $0.000^{\dagger}$ \\
\hline & \multirow{3}{*}{ Onion } & $\mathrm{L}^{*}$ & 721.5 & 4 & 180.4 & 682.5 & 145 & 4.71 & 38.31 & $0.000^{\dagger}$ \\
\hline & & $a^{*}$ & 43.54 & 4 & 10.89 & 120.0 & 145 & 0.83 & 13.56 & $0.000^{\dagger}$ \\
\hline & & $b^{*}$ & 41.84 & 4 & 10.46 & 210.9 & 145 & 1.45 & 7.190 & $0.000^{\dagger}$ \\
\hline \multirow{15}{*}{$\begin{array}{l}\text { Screw speed } \\
(\mathrm{rpm})\end{array}$} & \multirow{3}{*}{ Beetroot } & $\mathrm{L}^{*}$ & 17.15 & 2 & 8.580 & 2867 & 147 & 19.50 & 0.440 & 0.645 \\
\hline & & $a^{*}$ & 0.885 & 2 & 0.440 & 1007 & 147 & 6.85 & 0.060 & 0.938 \\
\hline & & $b^{*}$ & 3.460 & 2 & 1.730 & 5110 & 147 & 34.76 & 0.050 & 0.951 \\
\hline & \multirow{3}{*}{ Carrot } & $\mathrm{L}^{*}$ & 10.26 & 2 & 5.130 & 2216 & 147 & 15.08 & 0.340 & 0.710 \\
\hline & & $a^{*}$ & 6.330 & 2 & 3.140 & 291.9 & 147 & 1.99 & 1.590 & 0.210 \\
\hline & & $b^{*}$ & 14.62 & 2 & 7.310 & 1619 & 147 & 11.02 & 0.660 & 0.520 \\
\hline & \multirow{3}{*}{ Kale } & $\mathrm{L}^{*}$ & 14.98 & 2 & 7.490 & 6006 & 147 & 40.86 & 0.180 & 0.830 \\
\hline & & $a^{*}$ & 1.140 & 2 & 0.700 & 124.8 & 147 & 0.85 & 0.830 & 0.436 \\
\hline & & $b^{*}$ & 7.290 & 2 & 3.640 & 726.9 & 147 & 4.94 & 0.740 & 0.480 \\
\hline & \multirow{3}{*}{ Leek } & $\mathrm{L}^{*}$ & 4.880 & 2 & 2.440 & 1417 & 147 & 9.64 & 0.260 & 0.777 \\
\hline & & $a^{*}$ & 7.970 & 2 & 3.990 & 127.8 & 147 & 0.87 & 4.580 & $0.012^{\dagger}$ \\
\hline & & $b^{*}$ & 48.33 & 2 & 24.16 & 416.2 & 147 & 2.83 & 8.530 & $0.000^{\dagger}$ \\
\hline & \multirow{3}{*}{ Onion } & $\mathrm{L}^{*}$ & 9.090 & 2 & 4.540 & 1395 & 147 & 9.49 & 0.480 & 0.620 \\
\hline & & $a^{*}$ & 5.230 & 2 & 2.620 & 158.3 & 147 & 1.08 & 2.430 & 0.092 \\
\hline & & $b^{*}$ & 3.840 & 2 & 1.920 & 248.9 & 147 & 1.69 & 1.130 & 0.320 \\
\hline \multirow{15}{*}{$\begin{array}{l}\text { Content of the } \\
\text { additive }(\%) \times \\
\text { Screw speed } \\
(\mathrm{rpm})\end{array}$} & \multirow{3}{*}{ Beetroot } & $\mathrm{L}^{*}$ & 2239 & 14 & 159.9 & 644.6 & 135 & 4.77 & 33.50 & $0.000^{\dagger}$ \\
\hline & & $a^{*}$ & 865.3 & 14 & 61.81 & 142.8 & 135 & 1.06 & 58.44 & $0.000^{\dagger}$ \\
\hline & & $b^{*}$ & 4801 & 14 & 342.9 & 312.3 & 135 & 2.31 & 148.2 & $0.000^{\dagger}$ \\
\hline & \multirow{3}{*}{ Carrot } & $\mathrm{L}^{*}$ & 1963 & 14 & 140.2 & 264.1 & 135 & 1.96 & 71.66 & $0.000^{\dagger}$ \\
\hline & & $a^{*}$ & 206.3 & 14 & 14.74 & 91.82 & 135 & 0.68 & 21.66 & $0.000^{\dagger}$ \\
\hline & & $b^{*}$ & 1514 & 14 & 108.1 & 120.3 & 135 & 0.89 & 121.3 & $0.000^{\dagger}$ \\
\hline & \multirow{3}{*}{ Kale } & $\mathrm{L}^{*}$ & 5353 & 14 & 382.4 & 667.6 & 135 & 4.95 & 77.32 & $0.000^{\dagger}$ \\
\hline & & $a^{*}$ & 18.41 & 14 & 1.310 & 107.8 & 135 & 0.80 & 1.650 & 0.074 \\
\hline & & $b^{*}$ & 521.4 & 14 & 37.24 & 212.8 & 135 & 1.58 & 23.62 & $0.000^{\dagger}$ \\
\hline & \multirow{3}{*}{ Leek } & $\mathrm{L}^{*}$ & 997.0 & 14 & 71.22 & 424.7 & 135 & 3.15 & 22.64 & $0.000^{\dagger}$ \\
\hline & & $a^{*}$ & 57.15 & 14 & 4.080 & 78.64 & 135 & 0.58 & 7.010 & $0.000^{\dagger}$ \\
\hline & & $b^{*}$ & 343.1 & 14 & 24.51 & 121.4 & 135 & 0.90 & 27.26 & $0.000^{\dagger}$ \\
\hline & \multirow{3}{*}{ Onion } & $\mathrm{L}^{*}$ & 835.8 & 14 & 59.70 & 568.1 & 135 & 4.21 & 14.19 & $0.000^{\dagger}$ \\
\hline & & $a^{*}$ & 73.79 & 14 & 5.270 & 89.74 & 135 & 0.66 & 7.930 & $0.000^{\dagger}$ \\
\hline & & $b^{*}$ & 54.31 & 14 & 3.880 & 198.5 & 135 & 1.47 & 2.640 & $0.002^{\dagger}$ \\
\hline
\end{tabular}

$\mathrm{L}^{*}$ - lightness; $\mathrm{a}^{*}$ - balance between redness $(+)$ and greenness $(-) ; \mathrm{b}^{*}-$ balance between yellowness $(+)$ and blueness $(-) ;{ }^{\dagger}$ indicates significant effect at $\alpha=0.05$. 
Table 4. The texture profile $(n=2)$ of rice-based snacks enriched with fresh vegetable pulp addition processed at various screw speeds

\begin{tabular}{|c|c|c|c|c|c|c|c|}
\hline $\begin{array}{l}\text { Vegetable } \\
\text { type }\end{array}$ & $\begin{array}{c}\text { Additive } \\
\text { amount }(\%)\end{array}$ & $\begin{array}{l}\text { Screw } \\
\text { speed } \\
(\mathrm{rpm})\end{array}$ & $\mathrm{H}(\mathrm{N})$ & $\mathrm{CR}(\mathrm{N})$ & $\mathrm{FR}(\mathrm{N})$ & S (-) & $\mathrm{C}(\mathrm{N})$ \\
\hline \multirow{3}{*}{$\begin{array}{l}\text { Rice } \\
\text { snacks }\end{array}$} & \multirow{3}{*}{0} & 80 & $521.0 \pm 11.00^{\mathrm{e}}$ & $9.76 \pm 3.14^{\mathrm{bc}}$ & $420.5 \pm 20.64^{\mathrm{de}}$ & $1.08 \pm 0.01^{\mathrm{c}}$ & $0.08 \pm 0.02^{\mathrm{b}}$ \\
\hline & & 100 & $421.0 \pm 7.00^{\mathrm{b}}$ & $11.43 \pm 3.07^{\mathrm{cd}}$ & $374.0 \pm 16.00^{\mathrm{d}}$ & $0.95 \pm 0.16^{\mathrm{bc}}$ & $0.10 \pm 0.03^{\mathrm{bc}}$ \\
\hline & & 120 & $474.5 \pm 6.50^{\mathrm{de}}$ & $12.44 \pm 1.74^{\mathrm{d}}$ & $415.0 \pm 3.00^{\mathrm{de}}$ & $0.90 \pm 0.09^{\mathrm{bc}}$ & $0.11 \pm 0.02^{\mathrm{c}}$ \\
\hline \multirow{12}{*}{ Beetroot } & \multirow{3}{*}{2.5} & 80 & $425.0 \pm 18.00^{\mathrm{bc}}$ & $3.55 \pm 2.37^{\mathrm{a}}$ & $372.0 \pm 4.00^{\mathrm{d}}$ & $1.33 \pm 0.43^{\mathrm{e}}$ & $0.02 \pm 0.01^{\mathrm{a}}$ \\
\hline & & 100 & $474.5 \pm 13.50^{\mathrm{de}}$ & $7.18 \pm 1.10^{\mathrm{ab}}$ & $368.0 \pm 17.00^{\mathrm{d}}$ & $1.40 \pm 0.28^{\mathrm{e}}$ & $0.05 \pm 0.01^{\mathrm{ab}}$ \\
\hline & & 120 & $460.0 \pm 1.00^{\mathrm{de}}$ & $5.86 \pm 0.48^{\mathrm{ab}}$ & $391.0 \pm 4.00^{\mathrm{de}}$ & $1.21 \pm 0.14^{\mathrm{d}}$ & $0.03 \pm 0.02^{\mathrm{a}}$ \\
\hline & \multirow{3}{*}{5.0} & 80 & $368.0 \pm 18.00^{\mathrm{ab}}$ & $7.10 \pm 2.88^{\mathrm{ab}}$ & $294.0 \pm 6.00^{\mathrm{bc}}$ & $1.34 \pm 0.04^{\mathrm{e}}$ & $0.09 \pm 0.01^{b c}$ \\
\hline & & 100 & $364.0 \pm 11.00^{\mathrm{ab}}$ & $15.22 \pm 2.88^{\mathrm{e}}$ & $338.0 \pm 12.00^{\mathrm{cd}}$ & $0.97 \pm 0.14^{\mathrm{bc}}$ & $0.07 \pm 0.01^{\mathrm{b}}$ \\
\hline & & 120 & $358.0 \pm 9.00^{\mathrm{ab}}$ & $6.46 \pm 0.12^{\mathrm{ab}}$ & $204.5 \pm 19.50^{\mathrm{a}}$ & $1.03 \pm 0.01^{\mathrm{bc}}$ & $0.10 \pm 0.01^{\mathrm{bc}}$ \\
\hline & \multirow{3}{*}{7.5} & 80 & $397.0 \pm 9.00^{\mathrm{ab}}$ & $7.83 \pm 3.87^{\mathrm{ab}}$ & $304.0 \pm 8.00^{c}$ & $1.33 \pm 0.43^{\mathrm{cd}}$ & $0.04 \pm 0.02^{\mathrm{a}}$ \\
\hline & & 100 & $371.5 \pm 5.50^{\mathrm{ab}}$ & $9.90 \pm 3.71^{\mathrm{bc}}$ & $304.5 \pm 7.50^{c}$ & $1.01 \pm 0.06^{\mathrm{c}}$ & $0.06 \pm 0.01^{\mathrm{ab}}$ \\
\hline & & 120 & $380.0 \pm 15.00^{\mathrm{ab}}$ & $12.70 \pm 0.70^{\mathrm{d}}$ & $365.5 \pm 9.50^{\mathrm{d}}$ & $0.98 \pm 0.04^{\mathrm{bc}}$ & $0.04 \pm 0.01^{\mathrm{a}}$ \\
\hline & \multirow{3}{*}{10.0} & 80 & $434.0 \pm 18.00^{\mathrm{bc}}$ & $15.30 \pm 2.80^{\mathrm{e}}$ & $431.5 \pm 15.50^{\mathrm{e}}$ & $1.12 \pm 0.09^{\mathrm{cd}}$ & $0.03 \pm 0.01^{\mathrm{a}}$ \\
\hline & & 100 & $432.0 \pm 2.00^{\mathrm{bc}}$ & $11.95 \pm 3.35^{\mathrm{cd}}$ & $430.8 \pm 0.75^{\mathrm{e}}$ & $1.26 \pm 0.15^{\mathrm{de}}$ & $0.03 \pm 0.00^{\mathrm{a}}$ \\
\hline & & 120 & $406.0 \pm 3.00^{\mathrm{b}}$ & $8.61 \pm 2.00^{\mathrm{b}}$ & $430.0 \pm 15.00^{\mathrm{e}}$ & $1.41 \pm 0.11^{\mathrm{e}}$ & $0.03 \pm 0.02^{\mathrm{a}}$ \\
\hline \multirow{12}{*}{ Carrot } & \multirow{3}{*}{2.5} & 80 & $357.5 \pm 16.50^{\mathrm{ab}}$ & $1.82 \pm 0.53^{\mathrm{a}}$ & $181.7 \pm 6.35^{\mathrm{a}}$ & $1.00 \pm 0.09^{\mathrm{c}}$ & $0.07 \pm 0.02^{\mathrm{b}}$ \\
\hline & & 100 & $439.5 \pm 17.50^{\mathrm{bc}}$ & $12.02 \pm 2.88^{\mathrm{cd}}$ & $283.5 \pm 12.50^{\mathrm{bc}}$ & $0.73 \pm 0.26^{\mathrm{ab}}$ & $0.04 \pm 0.01^{\mathrm{a}}$ \\
\hline & & 120 & $438.0 \pm 10.00^{\mathrm{bc}}$ & $4.63 \pm 0.38^{\mathrm{a}}$ & $404.5 \pm 12.50^{\mathrm{de}}$ & $0.86 \pm 0.06^{\mathrm{b}}$ & $0.04 \pm 0.02^{\mathrm{a}}$ \\
\hline & \multirow{3}{*}{5.0} & 80 & $351.5 \pm 19.50^{\mathrm{ab}}$ & $6.30 \pm 1.15^{\mathrm{ab}}$ & $314.5 \pm 14.50^{\mathrm{c}}$ & $1.11 \pm 0.27^{\mathrm{c}}$ & $0.04 \pm 0.02^{\mathrm{a}}$ \\
\hline & & 100 & $386.5 \pm 16.50^{\mathrm{ab}}$ & $6.21 \pm 3.57^{\mathrm{ab}}$ & $326.5 \pm 15.50^{\mathrm{cd}}$ & $1.40 \pm 0.42^{\mathrm{e}}$ & $0.03 \pm 0.02^{\mathrm{a}}$ \\
\hline & & 120 & $365.0 \pm 6.00^{\mathrm{ab}}$ & $5.53 \pm 0.86^{\mathrm{ab}}$ & $302.5 \pm 1.50^{c}$ & $0.73 \pm 0.35^{\mathrm{ab}}$ & $0.06 \pm 0.02^{\mathrm{ab}}$ \\
\hline & \multirow{3}{*}{7.5} & 80 & $502.0 \pm 13.00^{\mathrm{de}}$ & $10.80 \pm 0.80^{\mathrm{c}}$ & $468.5 \pm 16.50^{\mathrm{e}}$ & $1.07 \pm 0.06^{\mathrm{c}}$ & $0.06 \pm 0.01^{\mathrm{ab}}$ \\
\hline & & 100 & $358.5 \pm 9.50^{\mathrm{ab}}$ & $18.55 \pm 3.65^{\mathrm{e}}$ & $263.5 \pm 10.50^{\mathrm{b}}$ & $1.41 \pm 0.21^{\mathrm{e}}$ & $0.02 \pm 0.01^{\mathrm{a}}$ \\
\hline & & 120 & $441.5 \pm 6.50^{\mathrm{cd}}$ & $12.11 \pm 1.48^{\mathrm{d}}$ & $296.0 \pm 8.00^{\mathrm{bc}}$ & $0.57 \pm 0.14^{\mathrm{a}}$ & $0.08 \pm 0.02^{\mathrm{b}}$ \\
\hline & \multirow{3}{*}{10.0} & 80 & $520.0 \pm 19.00^{\mathrm{e}}$ & $12.28 \pm 1.03^{\mathrm{d}}$ & $220.5 \pm 10.00^{\mathrm{ab}}$ & $0.92 \pm 0.42^{\mathrm{bc}}$ & $0.07 \pm 0.04^{b}$ \\
\hline & & 100 & $400.5 \pm 5.50^{\mathrm{b}}$ & $10.76 \pm 1.05^{\mathrm{c}}$ & $313.0 \pm 18.00^{\mathrm{c}}$ & $0.78 \pm 0.64^{\mathrm{ab}}$ & $0.08 \pm 0.05^{\mathrm{b}}$ \\
\hline & & 120 & $435.0 \pm 19.00^{c}$ & $10.59 \pm 1.01^{\mathrm{c}}$ & $366.0 \pm 18.00^{\mathrm{d}}$ & $1.25 \pm 0.22^{\mathrm{de}}$ & $0.07 \pm 0.04^{\mathrm{b}}$ \\
\hline \multirow{12}{*}{ Kale } & \multirow{3}{*}{2.5} & 80 & $446.0 \pm 16.00^{\mathrm{cd}}$ & $10.93 \pm 2.07^{\mathrm{c}}$ & $374.0 \pm 11.00^{\mathrm{d}}$ & $0.87 \pm 0.13^{\mathrm{b}}$ & $0.08 \pm 0.02^{\mathrm{b}}$ \\
\hline & & 100 & $392.0 \pm 14.00^{\mathrm{ab}}$ & $12.00 \pm 0.91^{\mathrm{d}}$ & $338.5 \pm 6.50^{\mathrm{cd}}$ & $1.27 \pm 0.45^{\mathrm{de}}$ & $0.11 \pm 0.07^{\mathrm{c}}$ \\
\hline & & 120 & $528.0 \pm 11.00^{\mathrm{e}}$ & $11.22 \pm 0.18^{\mathrm{c}}$ & $499.0 \pm 18.00^{\mathrm{e}}$ & $0.94 \pm 0.04^{\mathrm{bc}}$ & $0.08 \pm 0.02^{\mathrm{b}}$ \\
\hline & \multirow{3}{*}{5.0} & 80 & $445.5 \pm 17.50^{\mathrm{cd}}$ & $11.87 \pm 1.47^{\mathrm{cd}}$ & $385.5 \pm 27.50^{\mathrm{de}}$ & $0.92 \pm 0.02^{\mathrm{bc}}$ & $0.07 \pm 0.01^{\mathrm{b}}$ \\
\hline & & 100 & $410.5 \pm 17.50^{\mathrm{b}}$ & $14.80 \pm 1.80^{\mathrm{de}}$ & $333.5 \pm 8.50^{\mathrm{cd}}$ & $0.70 \pm 0.06^{\mathrm{ab}}$ & $0.07 \pm 0.01^{\mathrm{b}}$ \\
\hline & & 120 & $347.0 \pm 7.00^{\mathrm{a}}$ & $12.31 \pm 1.11^{\mathrm{d}}$ & $336.5 \pm 2.50^{\mathrm{cd}}$ & $1.09 \pm 0.29^{c}$ & $0.08 \pm 0.03^{b}$ \\
\hline & \multirow{3}{*}{7.5} & 80 & $356.5 \pm 2.50^{\mathrm{ab}}$ & $12.04 \pm 0.42^{\mathrm{d}}$ & $337.0 \pm 3.00^{\mathrm{cd}}$ & $0.87 \pm 0.13^{\mathrm{b}}$ & $0.12 \pm 0.01^{\mathrm{c}}$ \\
\hline & & 100 & $442.5 \pm 10.50^{\mathrm{cd}}$ & $13.02 \pm 0.08^{\mathrm{d}}$ & $406.0 \pm 17.00^{\mathrm{de}}$ & $1.17 \pm 0.20^{\mathrm{cd}}$ & $0.03 \pm 0.01^{\mathrm{a}}$ \\
\hline & & 120 & $384.5 \pm 14.50^{\mathrm{ab}}$ & $12.10 \pm 0.11^{\mathrm{d}}$ & $363.5 \pm 15.50^{\mathrm{d}}$ & $1.33 \pm 0.58^{\mathrm{e}}$ & $0.05 \pm 0.03^{\mathrm{ab}}$ \\
\hline & \multirow{3}{*}{10.0} & 80 & $404.0 \pm 15.00^{\mathrm{b}}$ & $15.26 \pm 1.94^{\mathrm{de}}$ & $379.0 \pm 20.00^{\mathrm{d}}$ & $1.29 \pm 0.35^{\mathrm{de}}$ & $0.04 \pm 0.01^{\mathrm{a}}$ \\
\hline & & 100 & $486.0 \pm 12.00^{\mathrm{de}}$ & $11.79 \pm 0.52^{\mathrm{cd}}$ & $378.0 \pm 19.00^{\mathrm{d}}$ & $1.04 \pm 0.27^{\mathrm{c}}$ & $0.02 \pm 0.02^{\mathrm{a}}$ \\
\hline & & 120 & $353.0 \pm 9.00^{\mathrm{ab}}$ & $14.06 \pm 1.15^{\mathrm{de}}$ & $339.0 \pm 14.00^{\mathrm{c}}$ & $1.34 \pm 0.40^{\mathrm{e}}$ & $0.04 \pm 0.01^{\mathrm{a}}$ \\
\hline & \multirow{3}{*}{2.5} & 80 & $427.5 \pm 15.50^{\mathrm{bc}}$ & $12.21 \pm 0.90^{\mathrm{d}}$ & $345.0 \pm 16.00^{\mathrm{cd}}$ & $0.83 \pm 0.02^{\mathrm{b}}$ & $0.08 \pm 0.01^{\mathrm{b}}$ \\
\hline & & 100 & $467.5 \pm 19.50^{\mathrm{d}}$ & $14.25 \pm 6.65^{\mathrm{de}}$ & $376.0 \pm 4.00^{\mathrm{d}}$ & $0.86 \pm 0.03^{\mathrm{b}}$ & $0.06 \pm 0.01^{\mathrm{ab}}$ \\
\hline & & 120 & $448.5 \pm 8.50^{\mathrm{cd}}$ & $14.23 \pm 2.78^{\mathrm{de}}$ & $370.0 \pm 15.00^{\mathrm{cd}}$ & $1.26 \pm 0.38^{\mathrm{de}}$ & $0.04 \pm 0.02^{\mathrm{a}}$ \\
\hline & \multirow{3}{*}{5.0} & 80 & $389.5 \pm 17.50^{\mathrm{ab}}$ & $11.27 \pm 0.97^{\mathrm{cd}}$ & $327.0 \pm 11.00^{\mathrm{cd}}$ & $0.75 \pm 0.19^{\mathrm{ab}}$ & $0.06 \pm 0.01^{\mathrm{ab}}$ \\
\hline & & 100 & $440.5 \pm 18.50^{c}$ & $13.44 \pm 1.69^{d}$ & $362.5 \pm 17.50^{\mathrm{d}}$ & $1.02 \pm 0.03^{\mathrm{c}}$ & $0.05 \pm 0.04^{\mathrm{ab}}$ \\
\hline I & & 120 & $416.0 \pm 11.00^{b}$ & $12.38 \pm 2.18^{\mathrm{d}}$ & $380.5 \pm 16.50^{\mathrm{d}}$ & $1.01 \pm 0.19^{\mathrm{c}}$ & $0.05 \pm 0.01^{\mathrm{ab}}$ \\
\hline Leek & & 80 & $534.0 \pm 1.00^{\mathrm{e}}$ & $13.51 \pm 2.18^{\mathrm{d}}$ & $449.0 \pm 17.00^{\mathrm{e}}$ & $0.81 \pm 0.03^{\mathrm{b}}$ & $0.03 \pm 0.02^{\mathrm{a}}$ \\
\hline & 7.5 & 100 & $423.5 \pm 6.50^{\mathrm{bc}}$ & $11.14 \pm 2.04^{\mathrm{cd}}$ & $301.5 \pm 15.50^{\mathrm{c}}$ & $0.83 \pm 0.07^{\mathrm{b}}$ & $0.12 \pm 0.07^{\mathrm{c}}$ \\
\hline & & 120 & $397.5 \pm 31.50^{\mathrm{ab}}$ & $15.45 \pm 0.93^{\mathrm{de}}$ & $292.0 \pm 8.00^{\mathrm{bc}}$ & $1.00 \pm 0.08^{\mathrm{c}}$ & $0.07 \pm 0.02^{\mathrm{b}}$ \\
\hline & & 80 & $461.5 \pm 15.50^{\mathrm{d}}$ & $11.99 \pm 0.92^{\mathrm{cd}}$ & $444.5 \pm 19.50^{\mathrm{e}}$ & $0.86 \pm 0.11^{\mathrm{b}}$ & $0.09 \pm 0.03^{\mathrm{bc}}$ \\
\hline & 10.0 & 100 & $456.5 \pm 7.50^{\mathrm{cd}}$ & $13.58 \pm 0.52^{\mathrm{d}}$ & $415.0 \pm 5.00^{\mathrm{de}}$ & $0.99 \pm 0.01^{\mathrm{bc}}$ & $0.12 \pm 0.03^{\mathrm{c}}$ \\
\hline & & 120 & $353.0 \pm 20.00^{\mathrm{ab}}$ & $14.06 \pm 0.58^{\mathrm{de}}$ & $339.5 \pm 2.50^{c}$ & $1.34 \pm 0.22^{\mathrm{e}}$ & $0.04 \pm 0.03^{\mathrm{a}}$ \\
\hline
\end{tabular}

$\mathrm{H}$ - hardness, $\mathrm{CR}$ - crispness, $\mathrm{FR}$ - fracturability, $\mathrm{S}$ - springiness, $\mathrm{C}$ - cohesiveness; ${ }^{\text {a-e }}$ means indicated with similar letters in columns do not differ significantly at $\alpha=0.05$. 
Table 4. Continuation

\begin{tabular}{|c|c|c|c|c|c|c|c|}
\hline $\begin{array}{l}\text { Vegetable } \\
\text { type }\end{array}$ & $\begin{array}{c}\text { Additive } \\
\text { amount }(\%)\end{array}$ & $\begin{array}{l}\text { Screw } \\
\text { speed } \\
(\mathrm{rpm})\end{array}$ & $\mathrm{H}(\mathrm{N})$ & CR (N) & FR $(\mathrm{N})$ & S (-) & $\mathrm{C}(\mathrm{N})$ \\
\hline \multirow{4}{*}{ Onion } & 2.5 & $\begin{array}{r}80 \\
100 \\
120\end{array}$ & $\begin{array}{l}421.0 \pm 17.00^{\mathrm{bc}} \\
467.5 \pm 5.50^{\mathrm{d}} \\
438.5 \pm 7.50^{\mathrm{c}}\end{array}$ & $\begin{array}{l}12.22 \pm 0.10^{\mathrm{d}} \\
14.25 \pm 1.30^{\mathrm{de}} \\
14.54 \pm 0.76^{\mathrm{de}}\end{array}$ & $\begin{array}{l}306.5 \pm 7.50^{\mathrm{c}} \\
376.0 \pm 4.00^{\mathrm{d}} \\
349.0 \pm 13.00^{\mathrm{c}}\end{array}$ & $\begin{array}{l}1.28 \pm 0.35^{\mathrm{de}} \\
0.86 \pm 0.35^{\mathrm{b}} \\
0.85 \pm 0.05^{\mathrm{b}}\end{array}$ & $\begin{array}{l}0.05 \pm 0.04^{\mathrm{ab}} \\
0.06 \pm 0.03^{\mathrm{ab}} \\
0.07 \pm 0.01^{\mathrm{b}}\end{array}$ \\
\hline & 5.0 & $\begin{array}{r}80 \\
100 \\
120\end{array}$ & $\begin{array}{l}457.0 \pm 14.00^{\mathrm{cd}} \\
467.0 \pm 12.00^{\mathrm{d}} \\
448.5 \pm 9.50^{\mathrm{cd}}\end{array}$ & $\begin{array}{l}14.70 \pm 2.30^{\mathrm{de}} \\
11.02 \pm 0.22^{\mathrm{cd}} \\
13.24 \pm 1.51^{\mathrm{d}}\end{array}$ & $\begin{array}{l}346.0 \pm 10.00^{c} \\
381.5 \pm 15.50^{d} \\
377.5 \pm 13.50^{d}\end{array}$ & $\begin{array}{l}0.98 \pm 0.13^{\mathrm{bc}} \\
0.87 \pm 0.11^{\mathrm{b}} \\
1.31 \pm 0.37^{\mathrm{e}}\end{array}$ & $\begin{array}{l}0.06 \pm 0.02^{\mathrm{ab}} \\
0.06 \pm 0.02^{\mathrm{ab}} \\
0.04 \pm 0.02^{\mathrm{a}}\end{array}$ \\
\hline & 7.5 & $\begin{array}{r}80 \\
100 \\
120\end{array}$ & $\begin{array}{l}450.5 \pm 11.50^{\mathrm{cd}} \\
405.0 \pm 19.00^{\mathrm{b}} \\
367.5 \pm 6.50^{\mathrm{ab}}\end{array}$ & $\begin{array}{l}17.25 \pm 0.25^{\mathrm{e}} \\
16.53 \pm 3.68^{\mathrm{e}} \\
15.63 \pm 2.27^{\mathrm{de}}\end{array}$ & $\begin{array}{l}441.0 \pm 15.00^{\mathrm{e}} \\
339.5 \pm 19.50^{\mathrm{c}} \\
323.0 \pm 18.00^{\mathrm{c}}\end{array}$ & $\begin{array}{l}1.11 \pm 0.35^{\mathrm{cd}} \\
1.31 \pm 0.46^{\mathrm{e}} \\
0.96 \pm 0.01^{\mathrm{bc}}\end{array}$ & $\begin{array}{l}0.06 \pm 0.02^{\mathrm{ab}} \\
0.02 \pm 0.01^{\mathrm{a}} \\
0.07 \pm 0.03^{\mathrm{b}}\end{array}$ \\
\hline & 10.0 & $\begin{array}{r}80 \\
100 \\
120\end{array}$ & $\begin{array}{l}440.0 \pm 16.00^{\mathrm{c}} \\
328.5 \pm 13.50^{\mathrm{a}} \\
348.0 \pm 5.00^{\mathrm{a}}\end{array}$ & $\begin{array}{l}14.80 \pm 2.54^{\mathrm{de}} \\
12.83 \pm 2.63^{\mathrm{d}} \\
12.13 \pm 0.78^{\mathrm{d}}\end{array}$ & $\begin{array}{l}360.0 \pm 3.00^{\mathrm{cd}} \\
328.5 \pm 18.50^{\mathrm{c}} \\
279.5 \pm 3.50^{\mathrm{b}}\end{array}$ & $\begin{array}{l}1.27 \pm 0.07^{\mathrm{de}} \\
0.95 \pm 0.05^{\mathrm{bc}} \\
0.96 \pm 0.31^{\mathrm{bc}}\end{array}$ & $\begin{array}{l}0.05 \pm 0.01^{\mathrm{ab}} \\
0.08 \pm 0.02^{\mathrm{b}} \\
0.05 \pm 0.01^{\mathrm{ab}}\end{array}$ \\
\hline
\end{tabular}

$\mathrm{H}$ - hardness, $\mathrm{CR}$ - crispness, $\mathrm{FR}$ - fracturability, $\mathrm{S}$ - springiness, $\mathrm{C}$ - cohesiveness; ${ }^{\text {a-e }}$ means indicated with similar letters in columns do not differ significantly at $\alpha=0.05$.

application of fresh vegetable pulp in amounts not exceeding $5.0 \%(\mathrm{w} / \mathrm{w})$ lowered fracturability as compared to the control snacks. Furthermore, significant differences were noted between almost all of the snack products produced at 80 and $120 \mathrm{rpm}$ (Table 4). Additionally, interactions between the content of vegetable additives and screw speed had significant effects on the FR of the snack products which included beetroot and carrot pulp (Table 5).

Directly expanded snacks are crispy and not springy, so springiness values were low and varied from 1.41 in rice snacks supplemented with $10.0 \%(\mathrm{w} / \mathrm{w})$ beetroot pulp processed at $120 \mathrm{rpm}$, to $7.5 \%(\mathrm{w} / \mathrm{w})$ for snacks with carrot pulp processed at $100 \mathrm{rpm}$, and up to 0.57 for rice snack products enriched with the addition of $7.5 \%(\mathrm{w} / \mathrm{w})$ carrot pulp extruded at $120 \mathrm{rpm}$. With regard to the amount of vegetable pulp used and the variable screw speed achieved and interactions tested, no significant effects on $\mathrm{S}$ were found between all of the tested extrudates (Table 4).

The cohesiveness of these kinds of products is low due to the porous and expanded structure of extruded snack products. The highest values of $\mathrm{C}(0.12 \mathrm{~N})$ were found in rice snack products supplemented with $7.5 \%(\mathrm{w} / \mathrm{w})$ kale pulp processed at $80 \mathrm{rpm}$ or 7.5 and $10.0 \%(\mathrm{w} / \mathrm{w})$ leek pulp processed at $100 \mathrm{rpm}$. Due to the type of vegetable used, significant differences were found between the control rice snack products and snacks supplemented with a high content of beetroot and kale pulp (Table 4). However, independent variable interactions only showed a significant effect on $\mathrm{C}$ for snacks enriched with beetroot pulp, while the amount of additive had a significant effect on the cohesiveness of snacks with beetroot, carrot and kale pulp addition (Table 5).

Wójtowicz et al. (2018) added freeze-dried tomato to corn extrudates with the assumption that only snacks with a rating above 5 points were considered acceptable within a 9-point hedonic evaluation. Based on this assumption, all snacks containing $10.0 \%(\mathrm{w} / \mathrm{w})$ of vegetable pulp, with the exception of kale fortified snacks, may be considered undesirable.

Figure 5 shows the results of the consumer acceptability of snacks enriched with fresh vegetable pulps. In all cases, regardless of the rotational speed applied, the addition of $2.5 \%(\mathrm{w} / \mathrm{w})$ vegetable pulp to the extrudates increased the acceptability of the product among consumers, in comparison to the control rice snacks. Snacks supplemented with $2.5 \%(\mathrm{w} / \mathrm{w})$ leek pulp produced at 80 and $100 \mathrm{rpm}$ ( 7.6 and 7.05 , respectively) and with kale processed at $120 \mathrm{rpm}$ (7.5) were the most acceptable. The content of the additive and the interactions between content and screw speed, therefore, had significant effects on the acceptability results (Table 5).

The appearance of the tested snacks varied depending on the type of vegetable pulp applied. However, most of the snacks were visually attractive (Fig. 6), but other quality features resulted in the elimination of snacks with the highest content of fresh vegetables. Snacks with a $10.0 \%(w / w)$ addition of vegetables were characterized by a rough surface and an irregular shape, especially when beetroot, carrot or kale were used. The results of the sensory acceptability test showed that the aplication of fresh pulps of beetroot, carrot, kale, leek, and onion to fortify snacks above $7.5 \%$ $(w / w)$ is not recommended.

\section{CONCLUSIONS}

1. With increased screw speed, an increase in the processing efficiency of snack products enriched with vegetable pulps was noted. An increase in the specific mechanical energy, in particular, for snack items enriched with beetroot, carrot and onion pulp by up to $2.5 \%(\mathrm{w} / \mathrm{w})$ of the additive was also evident. 
Table 5. Results of analysis of variance of the effect of screw speed, additive type and interactions on texture profile and acceptability rice-based supplemented snacks

\begin{tabular}{|c|c|c|c|c|c|c|c|c|c|c|}
\hline $\begin{array}{l}\text { Independent } \\
\text { variable }\end{array}$ & $\begin{array}{l}\text { Additive } \\
\text { type }\end{array}$ & $\begin{array}{l}\text { Dependent } \\
\text { variable }\end{array}$ & $\begin{array}{l}\text { Sum of } \\
\text { squares } \\
\text { effect }\end{array}$ & $\begin{array}{c}\mathrm{df} \\
\text { effect }\end{array}$ & $\begin{array}{c}\text { Mean square } \\
\text { effect }\end{array}$ & $\begin{array}{l}\text { Sum of } \\
\text { squares } \\
\text { error }\end{array}$ & $\begin{array}{c}\mathrm{df} \\
\text { error }\end{array}$ & $\begin{array}{l}\text { Mean } \\
\text { square } \\
\text { error }\end{array}$ & F-test & $\begin{array}{c}p \\
\text { values }\end{array}$ \\
\hline \multirow{29}{*}{$\begin{array}{l}\text { Content of } \\
\text { the additive } \\
(\%)\end{array}$} & \multirow{6}{*}{ Beetroot } & $\mathrm{H}$ & 50555 & 4 & 12639 & 19313 & 25 & 772.6 & 16.36 & $0.000^{\dagger}$ \\
\hline & & $\mathrm{CR}$ & 146.7 & 4 & 37.42 & 381.3 & 25 & 15.25 & 2.450 & 0.072 \\
\hline & & FR & 89715 & 4 & 22429 & 51725 & 25 & 2069 & 10.84 & $0.000^{\dagger}$ \\
\hline & & $\mathrm{S}$ & 0.436 & 4 & 0.100 & 1.576 & 25 & 0.063 & 1.730 & 0.175 \\
\hline & & $\mathrm{C}$ & 0.023 & 4 & 0.006 & 0.009 & 25 & 0.000 & 15.80 & $0.000^{\dagger}$ \\
\hline & & A & 111.1 & 4 & 27.77 & 305.2 & 220 & 1.387 & 20.01 & $0.000^{\dagger}$ \\
\hline & \multirow{6}{*}{ Carrot } & $\mathrm{H}$ & 3842 & 4 & 9613 & 71237 & 25 & 2850 & 3.370 & $0.024^{\dagger}$ \\
\hline & & $\mathrm{CR}$ & 286.2 & 4 & 71.56 & 321.7 & 25 & 12.87 & 5.560 & $0.002^{\dagger}$ \\
\hline & & FR & 72106 & 4 & 17757 & 218393 & 25 & 8736 & 2.030 & 0.120 \\
\hline & & $\mathrm{S}$ & 0.151 & 4 & 0.038 & 3.870 & 25 & 0.155 & 0.240 & 0.911 \\
\hline & & $\mathrm{C}$ & 0.018 & 4 & 0.003 & 0.023 & 25 & 0.009 & 3.240 & $0.028^{\dagger}$ \\
\hline & & A & 252.2 & 4 & 63.05 & 247.5 & 220 & 1.125 & 56.05 & $0.000^{\dagger}$ \\
\hline & \multirow{6}{*}{ Kale } & $\mathrm{H}$ & 28406 & 4 & 7102 & 84779 & 25 & 3391 & 2.090 & 0.112 \\
\hline & & $\mathrm{CR}$ & 26.87 & 4 & 6.72 & 111.4 & 25 & 4.450 & 1.510 & 0.230 \\
\hline & & FR & 13368 & 4 & 3342 & 69651 & 25 & 2786 & 1.200 & 0.336 \\
\hline & & $\mathrm{S}$ & 0.375 & 4 & 0.094 & 2.832 & 25 & 0.013 & 0.830 & 0.521 \\
\hline & & $\mathrm{C}$ & 0.015 & 4 & 0.004 & 0.032 & 25 & 0.001 & 2.890 & $0.043^{\dagger}$ \\
\hline & & A & 56.21 & 4 & 14.05 & 143.4 & 220 & 0.652 & 21.57 & $0.000^{\dagger}$ \\
\hline & \multirow{6}{*}{ Leek } & $\mathrm{H}$ & 9982 & 4 & 2496 & 46112 & 25 & 1844 & 1.350 & 0.278 \\
\hline & & $\mathrm{CR}$ & 108.7 & 4 & 27.17 & 391.5 & 25 & 15.66 & 1.740 & 0.174 \\
\hline & & FR & 12856 & 4 & 3214 & 92729 & 25 & 3709 & 0.870 & 0.498 \\
\hline & & $\mathrm{S}$ & 0.085 & 4 & 0.021 & 1.115 & 25 & 0.044 & 0.480 & 0.754 \\
\hline & & $\mathrm{C}$ & 0.007 & 4 & 0.002 & 0.036 & 25 & 0.001 & 1.22 & 0.326 \\
\hline & & A & 187.4 & 4 & 46.84 & 170.7 & 220 & 0.776 & 60.39 & $0.000^{\dagger}$ \\
\hline & \multirow{6}{*}{ Onion } & $\mathrm{H}$ & 41122 & 4 & 10281 & 45451 & 25 & 1818 & 5.650 & $0.002^{\dagger}$ \\
\hline & & $\mathrm{CR}$ & 86.32 & 4 & 21.58 & 166.6 & 25 & 6.66 & 3.240 & $0.028^{\dagger}$ \\
\hline & & FR & 20778 & 4 & 5195 & 62968 & 25 & 2519 & 2.060 & 0.116 \\
\hline & & $\mathrm{S}$ & 0.112 & 4 & 0.028 & 2.505 & 25 & 0.100 & 0.280 & 0.888 \\
\hline & & $\mathrm{C}$ & 0.008 & 4 & 0.002 & 0.018 & 25 & 0.001 & 2.800 & $0.047^{\dagger}$ \\
\hline \multirow{19}{*}{$\begin{array}{l}\text { Screw } \\
\text { speed (rpm) }\end{array}$} & & A & 110.4 & 4 & 25.11 & 53.28 & 220 & 0.242 & 103.7 & $0.000^{\dagger}$ \\
\hline & \multirow{6}{*}{ Beetroot } & $\mathrm{H}$ & 1518 & 2 & 759.1 & 68353 & 27 & 2532 & 0.300 & 0.743 \\
\hline & & $\mathrm{CR}$ & 32.83 & 2 & 16.42 & 498.2 & 27 & 18.45 & 0.890 & 0.422 \\
\hline & & FR & 51.56 & 2 & 25.78 & 141389 & 27 & 5237 & 0.010 & 0.995 \\
\hline & & $\mathrm{S}$ & 0.108 & 2 & 0.054 & 1.903 & 27 & 0.070 & 0.770 & 0.473 \\
\hline & & $\mathrm{C}$ & 0.001 & 2 & 0.000 & 0.031 & 27 & 0.001 & 0.330 & 0.718 \\
\hline & & A & 0.438 & 2 & 0.188 & 415.9 & 222 & 1.874 & 0.100 & 0.095 \\
\hline & \multirow{6}{*}{ Carrot } & $\mathrm{H}$ & 14478 & 2 & 7239 & 95212 & 27 & 3526 & 2.050 & 0.148 \\
\hline & & $\mathrm{CR}$ & 0.71 & 2 & 35.35 & 537.2 & 27 & 19.90 & 1.780 & 0.188 \\
\hline & & FR & 17397 & 2 & 8697 & 272022 & 27 & 10075 & 0.860 & 0.433 \\
\hline & & $\mathrm{S}$ & 0.220 & 2 & 0.110 & 3.818 & 27 & 0.141 & 0.780 & 0.469 \\
\hline & & $\mathrm{C}$ & 0.001 & 2 & 0.001 & 0.034 & 27 & 0.001 & 0.450 & 0.639 \\
\hline & & A & 5.511 & 2 & 2.755 & 494.1 & 222 & 2.226 & 1.240 & 0.291 \\
\hline & \multirow{6}{*}{ Kale } & $\mathrm{H}$ & 1608 & 2 & 804.1 & 111577 & 27 & 4132 & 0.190 & 0.842 \\
\hline & & $\mathrm{CR}$ & 2.13 & 2 & 1.07 & 136.1 & 27 & 5.040 & 0.210 & 0.810 \\
\hline & & FR & 3031 & 2 & 1516 & 79988 & 27 & 2962 & 0.510 & 0.605 \\
\hline & & $\mathrm{S}$ & 0.075 & 2 & 0.038 & 3.131 & 27 & 0.116 & 0.330 & 0.725 \\
\hline & & $\mathrm{C}$ & 0.000 & 2 & 0.000 & 0.046 & 27 & 0.002 & 0.120 & 0.887 \\
\hline & & A & 3.920 & 2 & 1.960 & 195.7 & 222 & 0.881 & 2.240 & 0.110 \\
\hline
\end{tabular}

$\mathrm{H}$ - hardness, CR - crispness, FR - fracturability, $\mathrm{S}$ - springiness, $\mathrm{C}$ - cohesiveness, $\mathrm{A}$ - acceptability, ${ }^{\dagger}$ indicates significant effect at $\alpha=0.05$. 
Table 5. Continuation

\begin{tabular}{|c|c|c|c|c|c|c|c|c|c|c|}
\hline $\begin{array}{l}\text { Independent } \\
\text { variable }\end{array}$ & $\begin{array}{l}\text { Additive } \\
\text { type }\end{array}$ & $\begin{array}{l}\text { Dependent } \\
\text { variable }\end{array}$ & $\begin{array}{c}\text { Sum of } \\
\text { squares } \\
\text { effect }\end{array}$ & $\begin{array}{c}\mathrm{df} \\
\text { effect }\end{array}$ & $\begin{array}{c}\text { Mean } \\
\text { square } \\
\text { effect }\end{array}$ & $\begin{array}{l}\text { Sum of } \\
\text { squares } \\
\text { error }\end{array}$ & $\begin{array}{l}\mathrm{df} \\
\text { error }\end{array}$ & $\begin{array}{l}\text { Mean } \\
\text { square } \\
\text { error }\end{array}$ & F-test & $\begin{array}{c}p \\
\text { values }\end{array}$ \\
\hline \multirow{12}{*}{$\begin{array}{l}\text { Screw } \\
\text { speed (rpm) }\end{array}$} & \multirow{6}{*}{ Leek } & $\mathrm{H}$ & 6026 & 2 & 3013 & 50068 & 27 & 1854 & 1.62 & 0.216 \\
\hline & & $\mathrm{CR}$ & 47.07 & 2 & 23.53 & 453.1 & 27 & 16.78 & 1.40 & 0.263 \\
\hline & & FR & 10497 & 2 & 5248 & 95088 & 27 & 3522 & 1.49 & 0.243 \\
\hline & & $\mathrm{S}$ & 0.057 & 2 & 0.028 & 1.142 & 27 & 0.042 & 0.67 & 0.519 \\
\hline & & $\mathrm{C}$ & 0.004 & 2 & 0.002 & 0.039 & 27 & 0.002 & 1.38 & 0.270 \\
\hline & & A & 0.905 & 2 & 0.453 & 357.1 & 222 & 1.609 & 0.28 & 0.755 \\
\hline & \multirow{6}{*}{ Onion } & $\mathrm{H}$ & 10879 & 2 & 5440 & 75693 & 27 & 2803 & 1.94 & 0.163 \\
\hline & & CR & 2.750 & 2 & 1.37 & 250.1 & 27 & 9.26 & 0.15 & 0.863 \\
\hline & & FR & 3399 & 2 & 1699 & 80347 & 27 & 2976 & 0.57 & 0.572 \\
\hline & & $\mathrm{S}$ & 0.109 & 2 & 0.054 & 2.508 & 27 & 0.093 & 0.58 & 0.564 \\
\hline & & $\mathrm{C}$ & 0.000 & 2 & 0.000 & 0.026 & 27 & 0.001 & 0.13 & 0.875 \\
\hline & & A & 0.005 & 2 & 0.003 & 153.7 & 222 & 0.692 & 0.004 & 0.996 \\
\hline \multirow{30}{*}{$\begin{array}{l}\text { Content of } \\
\text { the additive } \\
(\%) \mathrm{x} \\
\text { Screw } \\
\text { speed (rpm) }\end{array}$} & \multirow{6}{*}{ Beetroot } & $\mathrm{H}$ & 64913 & 14 & 4637 & 4958 & 15 & 330.5 & 14.03 & $0.000^{\dagger}$ \\
\hline & & $\mathrm{CR}$ & 334.7 & 14 & 23.91 & 196.3 & 15 & 13.09 & 1.83 & 0.130 \\
\hline & & FR & 116418 & 14 & 8315.57 & 25023 & 15 & 1668 & 4.98 & $0.002^{\dagger}$ \\
\hline & & $\mathrm{S}$ & 0.903 & 14 & 0.065 & 1.109 & 15 & 0.074 & 0.87 & 0.598 \\
\hline & & $\mathrm{C}$ & 0.026 & 14 & 0.002 & 0.006 & 15 & 0.000 & 4.91 & $0.002^{\dagger}$ \\
\hline & & A & 111.9 & 14 & 7.992 & 304.4 & 210 & 1.450 & 5.51 & $0.000^{\dagger}$ \\
\hline & \multirow{6}{*}{ Carrot } & $\mathrm{H}$ & 100984 & 14 & 7213 & 8706 & 15 & 580.4 & 12.43 & $0.000^{\dagger}$ \\
\hline & & $\mathrm{CR}$ & 477.7 & 14 & 34.12 & 130.29 & 15 & 8.680 & 3.93 & $0.006^{\dagger}$ \\
\hline & & FR & 250859 & 14 & 17919 & 38560 & 15 & 2571 & 6.97 & $0.000^{\dagger}$ \\
\hline & & $\mathrm{S}$ & 1.660 & 14 & 0.119 & 2.377 & 15 & 0.158 & 0.748 & 0.703 \\
\hline & & $\mathrm{C}$ & 0.019 & 14 & 0.001 & 0.016 & 15 & 0.001 & 1.27 & 0.323 \\
\hline & & A & 274.4 & 14 & 19.74 & 223.2 & 210 & 1.063 & 18.57 & $0.000^{\dagger}$ \\
\hline & \multirow{6}{*}{ Kale } & $\mathrm{H}$ & 92858 & 14 & 6633 & 20327 & 15 & 1355 & 4.89 & $0.002^{\dagger}$ \\
\hline & & $\mathrm{CR}$ & 59.08 & 14 & 4.22 & 79.16 & 15 & 5.280 & 0.80 & 0.659 \\
\hline & & FR & 54717 & 14 & 3908 & 28302 & 15 & 1887 & 2.07 & 0.087 \\
\hline & & $\mathrm{S}$ & 1.062 & 14 & 0.076 & 2.145 & 15 & 0.143 & 0.53 & 0.878 \\
\hline & & $\mathrm{C}$ & 0.027 & 14 & 0.002 & 0.019 & 15 & 0.001 & 1.48 & 0.230 \\
\hline & & A & 63.22 & 14 & 4.515 & 136.4 & 210 & 0.649 & 6.95 & $0.000^{\dagger}$ \\
\hline & \multirow{6}{*}{ Leek } & $\mathrm{H}$ & 46361 & 14 & 3311 & 9733 & 15 & 648.9 & 5.10 & $0.002^{\dagger}$ \\
\hline & & CR & 310.6 & 14 & 22.19 & 189.6 & 15 & 12.64 & 1.76 & 0.146 \\
\hline & & FR & 71935 & 14 & 5138 & 33650 & 15 & 2243 & 2.29 & 0.062 \\
\hline & & $\mathrm{S}$ & 0.566 & 14 & 0.040 & 0.633 & 15 & 0.042 & 0.96 & 0.530 \\
\hline & & $\mathrm{C}$ & 0.022 & 14 & 0.002 & 0.022 & 15 & 0.002 & 1.06 & 0.457 \\
\hline & & A & 191.4 & 14 & 13.67 & 166.6 & 210 & 0.793 & 17.24 & $0.000^{\dagger}$ \\
\hline & \multirow{6}{*}{ Onion } & $\mathrm{H}$ & 77476 & 14 & 5534 & 9097 & 15 & 606.4 & 9.13 & $0.000^{\dagger}$ \\
\hline & & CR & 123.1 & 14 & 8.790 & 129.8 & 15 & 8.65 & 1.02 & 0.485 \\
\hline & & FR & 55445 & 14 & 3960 & 28301 & 15 & 1887 & 2.10 & 0.083 \\
\hline & & $\mathrm{S}$ & 0.874 & 14 & 0.062 & 1.743 & 15 & 0.116 & 0.54 & 0.873 \\
\hline & & $\mathrm{C}$ & 0.014 & 14 & 0.001 & 0.013 & 15 & 0.001 & 1.19 & 0.371 \\
\hline & & A & 101.4 & 14 & 7.240 & 52.35 & 210 & 0.249 & 29.04 & $0.000^{\dagger}$ \\
\hline
\end{tabular}

$\mathrm{H}$ - hardness, CR - crispness, FR - fracturability, $S$-springiness, C - cohesiveness, A - acceptability, ${ }^{\dagger}$ indicates significant effect at $\alpha=0.05$.

2. The presented results showed the various effects of the addition of different vegetable pulps on the physical properties and texture of the supplemented gluten-free snacks. The increased content of vegetable pulps had an impact on the reduction of the expansion index, as well as increasing the bulk density of the snack items.

3. The addition of fresh vegetable pulps darkened the final colour of the snack products. The colour profile was connected with the natural colour of the vegetables used.
The most intensive colour changes in the snacks were found if beetroot and kale pulps were applied as additives. The addition of fresh vegetable pulp to snack products processed at $80 \mathrm{rpm}$ decreased hardness as compared to the control rice snacks.

4. The use of fresh vegetable pulps is an interesting alternative to the artificial enriching of snack products and eliminates the additional drying processing steps that serve to preserve thermo-sensitive nutritive compounds. 
a)

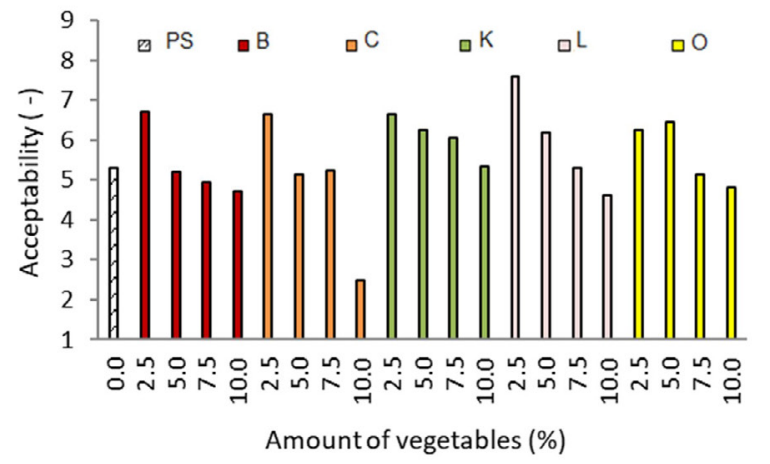

b)

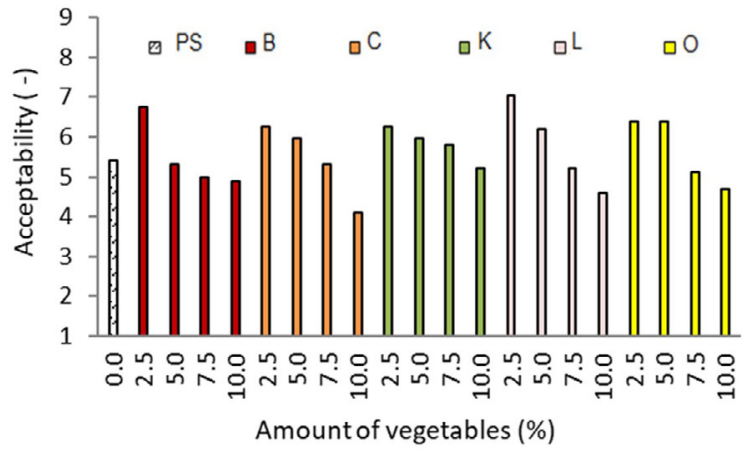

c)

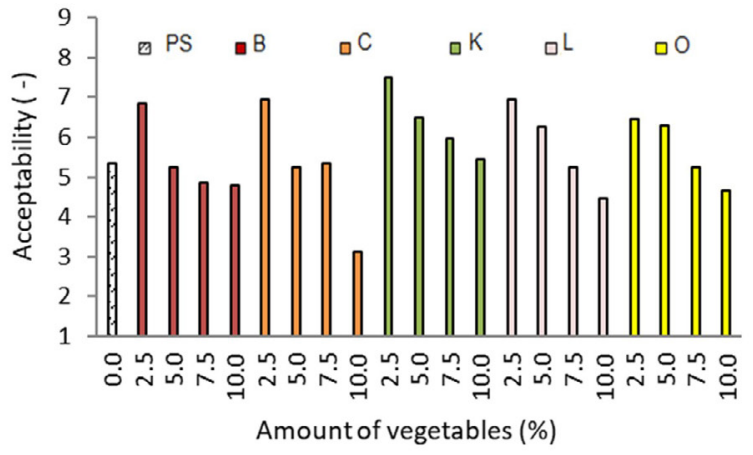

Fig. 5. Acceptability of rice-based snack products enriched with fresh vegetable pulps processed at various screw speeds: a) 80 rpm, b) $100 \mathrm{rpm}$, c) $120 \mathrm{rpm}$ : (PS) control pure rice snacks, (B) beetroot, (C) carrot, (K) kale, (L) leek, (O) onion.

Moreover, the natural colour of the vegetables used. The idea of applying fresh vegetable pulp appears to be beneficial for the food industry as it is economically efficient due to the omission of the energy spent on the drying treatment and consumption of water during typical extrusion processing. However, due to the factor of consumer acceptability, it is not recommended to fortify snacks above $7.5 \%(\mathrm{w} / \mathrm{w})$ with fresh pulps of beetroot, carrot, kale, leek and onion.

5. It is possible to produce an acceptable gluten-free snack product that has been enriched with vegetable additives.

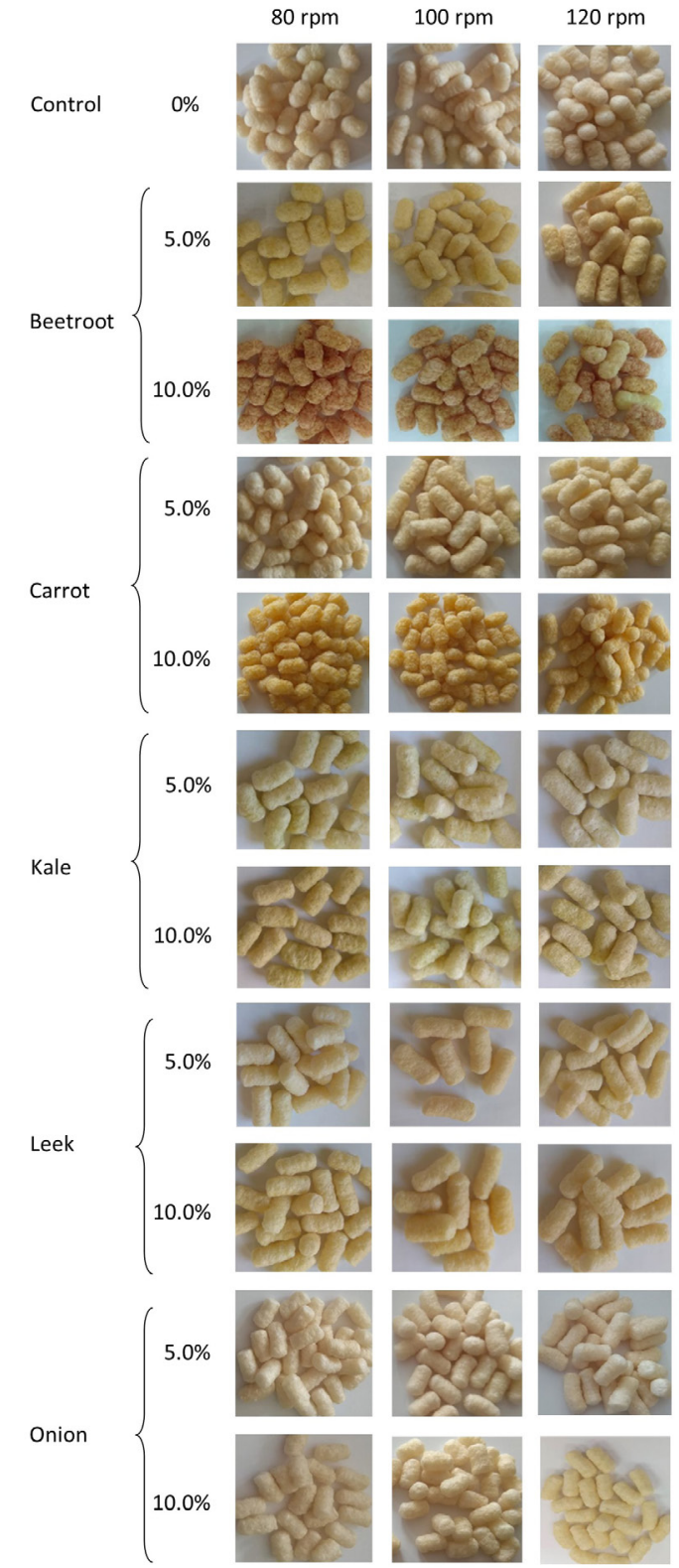

Fig. 6. View of extruded snacks supplemented with fresh vegetable pulps: control rice snacks, 5.0 and $10.0 \%(w / w)$ of beetroot, carrot, kale, leek and onion, respectively, processed at various screw speeds.

Conflicts of interest: The authors declare that they have no conflict of interest.

\section{REFERENCES}

AACC International, 2011. Approved Methods of Analysis. AACC International, St. Paul, USA.

Altan A., McCarthy K.L., and Maskan M., 2008. Evaluation of snack foods from barley-tomato pomace blends by extrusion processing. J. Food Eng., 84, 231-242. https://doi. org/10.1016/j.jfoodeng.2007.05.014 
Anton A.A., Fulcher R.G., and Arntfield S.D., 2009. Physical and nutritional impact of fortification of corn starch-based extruded snacks with common bean (Phaseolus vulgaris L.) flour: Effects of bean addition and extrusion cooking. Food Chem., 113, 989-996.

https://doi.org/10.1016/j.foodchem.2008.08.050

Baars A.E., Rubio-Valverde J.R., Hu Y., Bopp M., BrønnumHansen H., Kalediene R., Leinsalu M., Martikainen P., Regidor E., White Ch., Wojtyniak B., Mackenbach J.P., and Nusselder W.J., 2019. Fruit and vegetable consumption and its contribution to inequalities in life expectancy and disability-free life expectancy in ten European countries. Int. J. Public Health, 64, 861-872.

https://doi.org/10.1007/s00038-019-01253-w.

Baik B.K., Powers J., and Nguyen L.T., 2004. Extrusion of regular and waxy barley flours for production of expanded cereals. Cereal Chem., 8, 94-99. https://doi.org/10.1094/ CCHEM.2004.81.1.94|

Bascuñán K.A., Vespa M.C., and Araya M., 2017. Celiac disease: understanding the gluten free diet. Eur. J. Nutr., 56, 449-459. https://doi.org/10.1007/s00394-016-1238-5

Bisharat G.L., Lazou A.E., Panagiotou N.M., Krokida M.K., and Maroulis Z.B., 2015. Antioxidant potential and quality characteristics of vegetable-enriched corn-based extruded snacks. Int. J. Food Sci. Techol., 52, 3986-4000. https:// doi.org/10.1007/s13197-014-1519-Z

Chen Y., Liang Y., Jia F., Chen D., Zhang X., Wang Q., and Wang J., 2020. Effect of extrusion temperature on the protein aggregation of wheat gluten with the addition of peanut oil during extrusion. Int. J. Biol. Macromol., 166, 13771386. https://doi.org/10.1016/j.ijbiomac.2020.11.017

Darvishi H., Khoshtaghaza M.H., and Minaei S., 2014. Drying kinetics and colour change of lemon slices. Int. Agrophys., 28, 1-6. https://doi.org/10.2478/intag-2013-0021

Drabinska N., Ciska E., Szmatowicz B., and Krupa-Kozak U., 2018. Broccoli by-products improve the nutraceutical potential of gluten-free mini sponge cakes. Food Chem., 267, 170-177.

https://doi.org/10.1016/j.foodchem.2017.08.119

Food Industry Sustainability Strategy, 2006. Department for Environment, Food and Rural Affairs, www.defra.gov.uk

Hashemi N., Mortazavi S.A., Milani E., and Yazd F.T., 2017. Microstructural and textural properties of puffed snack prepared from partially defatted almond powder and corn flour. J. Food Process. Pres., 41, 12. https://doi.org/10.1111/ jfpp.13210

Korkerd S., Wanlapa S., Puttanlek C., Uttapap D., and Rungsardthong V., 2016. Expansion and functional properties of extruded snacks enriched with nutrition sources from food processing by-products. Int. J. Food Sci. Technol., 53, 561-570. https://doi.org/10.1007/s13197-015-2039-1

Kręcisz M., 2016. Energy consumption during production of corn extrudates in relation to the process parameters. Agric. Eng., 20, 125-131. https://doi.org/10.1515/agriceng-2016-0034

Krishnaraj P., Anukiruthika T., Choudhary P., Moses J.A., and Anandharamakrishnan C., 2019. 3D extrusion printing and post-processing of fibre-rich snack from indigenous composite flour. Food Bioproc. Tech., 12, 1776-1786. https://doi.org/10.1007/s11947-019-02336-5
Kunachowicz H., Nadolna I., Iwanow K., and Przygoda B., 2017. Tables of the composition and nutritional value of food (in Polish). PZWL, Warsaw, Poland.

Lisiecka K. and Wójtowicz A., 2020. Possibility to save water and energy by application of fresh vegetables to produce supplemented potato-based snack pellets. Processes, 8, 153. https://doi.org/10.3390/pr8020153

Lisiecka K., Wójtowicz A., Dziki D., and Gawlik-Dziki U., 2019. The influence of Cistus incanus $\mathrm{L}$. leaves on wheat pasta. Int. J. Food Sci. Technol., 56(9), 4311-4322. https:// doi.org/10.1007/s13197-019-03900-9

Lucas B.F., Morais M.G.D., Santos T.D., and Costa J.A.V., 2018. Spirulina for snack enrichment: Nutritional, physical and sensory evaluations. LWT-Food Sci. Technol., 90, 270-276. https://doi.org/10.1016/j.lwt.2017.12.032

Lucas González R., Viuda Martos J., Pérez Alvarez A., and Fernández López J., 2016. Antioxidant potential and quality characteristics of Mediterranean fruit based extruded snacks. Int. J. Food Sci. Techol., 51, 2674-2681. https://doi. org/10.1111/ijfs. 13257

Lv Y., Glahn R.P., Hebb R.L., and Rizvi S.S.H., 2018. Physicochemical properties, phytochemicals and DPPH radical scavenging activity of supercritical fluid extruded lentils. LWT-Food Sci. Technol., 89, 315-321.

https://doi.org/10.1016/j.lwt.2017.10.063

Meng X., Threinen D., Hansen M., and Driedger D., 2010. Effects of extrusion conditions on system parameters and physical properties of chickpea flour based snack. Food Res. Int., 43, 650-658. https://doi.org/10.1016/j.foodres.2009.07.016

Oyebode O., Gordon-Dseagu V., Walker A., and Mindell J.S., 2014. Fruit and vegetable consumption and all-cause, cancer and CVD mortality: analysis of Health Survey for England data. J. Epidemiol. Commun. H., 68, 856-862. http://dx.doi.org/10.1136/jech-2013-203500

Paraman I., Sharif M.K., Supriyadi S., and Rizvi S.S.H., 2015. Agro-food industry byproducts into value-added extruded foods. Food Bioprod. Process., 96, 78-85. https://doi. org/10.1016/j.fbp.2015.07.003

Pęksa A., Kita A., Carbonell-Barrachina A., Miedzianka J., Kolniak-Ostek J., Tajner-Czopek A., Rytel E., Siwek A., Miarka D., and Drożdż W., 2017. Sensory attributes and physicochemical features of corn snacks as affected by different flour types and extrusion conditions. LWT-Food Sci. Technol., 72, 26-36. https://doi.org/10.1016/j.lwt.2016.04.034

Poliszko N., Kowalczewski P.L., Rybicka I., Kubiak P., and Poliszko S., 2019. The effect of pumpkin flour on quality and acoustic properties of extruded corn snacks. LWT-Food Sci. Technol., 14, 121-129. https://doi.org/10.1007/s00003-019-01216-6

Rojas M.L., Silveira I., Esteves P., and Augusto D., 2020. Ultrasound and ethanol pre-treatments to improve convective drying: Drying, rehydration and carotenoid content of pumpkin. Food Bioprod. Process., 119, 20-30. https://doi. org/10.1016/j.fbp.2019.10.008

Shah F.U.H., Sharif M.K., Butt M.S., and Shahid M., 2017. Development of protein, dietary fiber, and micronutrient enriched extruded corn snacks. J. Texture Stud., 48, 221230. https://doi.org/10.1111/jtxs. 12231 
Shetty A.A., Magadum S., and Managanvi K., 2013. Vegetables as sources of antioxidants. J. Food Nutr. Disor., 2(1), 1000104.

http://dx.doi.org/10.4172/2324-9323.1000104

Singha P., Muthukumarappan K., and Krishnan P., 2018. Influence of processing conditions on apparent viscosity and system parameters during extrusion of distiller's dried grains-based snacks. Food Sci. Nutr., 6, 101-110. https:// doi.org/10.1002/fsn3.534

Stojceska V., Ainswirth P., Plunkett A., and Ibanoglu S., 2009. The effect of extrusion cooking using different water feed rates on quality of ready-to-eat snacks made from food byproducts. Food Chem., 114, 226-232.

https://doi.org/10.1016/j.foodchem.2008.09.043

Stojceska V., Ainsworth P., Plunkett A., İbanoğlu E., and İbanoğlu S., 2008. Cauliflower by-products as a new source of dietary fibre, antioxidants and proteins in cereal based ready-to-eat expanded snacks. J. Food Eng., 87, 554563. https://doi.org/10.1016/j.jfoodeng.2008.01.009

Usai-Satta P., Oppia F., Lai M., and Cabras F., 2017. Motility disorders in celiac disease and non-celiac gluten sensitivity: The impact of a gluten-free diet. Nutrients, 10(11), 1705. https://doi.org/10.3390/nu10111705

Wójtowicz A., Lisiecka K., Mitrus M., Nowak G., Golian M., Oniszczuk A., Kasprzak K., Widelska G., Oniszczuk T., and Combrzyński M., 2019. Physical properties and texture of gluten-free snacks supplemented with selected fruit additions. Int. Agrophys., 33, 407-416. https://doi.org/10.31545/intagr/112563

Wójtowicz A., Mitrus M., Oniszczuk T., Mościcki L., Kręcisz M., and Oniszczuk A., 2015. Selected physical properties, texture and sensory characteristics of extruded breakfast cereals based on wholegrain wheat flour. Agric. Agric. Sci. Proc., 7, 301-308.

https://doi.org/10.1016/j.aaspro.2015.12.051

Wójtowicz A., Oniszczuk A., Oniszczuk T., Kocira S., Wojtunik K., Mitrus M., Kocira A., Widelski J., and Skalicka-Woźniak K., 2017. Application of Moldavian dragonhead (Dracocephalum moldavica L.) leaves addition as a functional component of nutritionally valuable corn snacks. Int. J. Food Sci. Technol., 54, 3218-3229. https:// doi.org/10.1007/s13197-017-2765-7

Wójtowicz A., Zalewska-Korona M., Jabłońska-Ryś E., Skalicka-Woźniak K., and Oniszczuk A., 2018. Chemical characteristics and physical properties of functional snacks enriched with powdered tomato. Pol. J. Food Nutr. Sci., 68, 251-262. https://doi.org/10.1515/pjfns-2017-0028

Yağcı S. and Göğüș F., 2008. Response surface methodology for evaluation of physical and functional properties of extruded snack foods developed from food-by-products. J. Food Eng., 86, 122-132.

https://doi.org/10.1016/j.jfoodeng.2007.09.018 